\title{
ESSAYS
}

\author{
THEMA
}

\section{Spraakmakende lokale bestuurders en grensverleggend lokaal bestuur ${ }^{*}$}

\author{
Rik Reussing
}

In dit essay gaat de auteur op zoek naar spraakmakende lokale bestuurders die bestaande grenzen durfden te verleggen. Het verhaal start overigens in Groot-Brittannië waar progressieve liberalen onder de noemer 'municipal socialism' overgingen tot het door de gemeente verschaffen van publieke nutsvoorzieningen. Hun voorbeeld werd overgenomen door de Amsterdamse radicalen onder aanvoering van Wim Treub. Nog een stap verder ging het wethouderssocialisme met Floor Wibaut als belangrijkste vertegenwoordiger. Hun streven naar de verzorgingsgemeente liep vooruit op de latere verzorgingsstaat. Ook na de Tweede Wereldoorlog zien we sterke lokale bestuurders die ieder op hun eigen manier veranderingen binnen de gemeente nastreefden. Dat leidde na 1970 met de stadsvernieuwing tot een tweede bloeiperiode van het wethouderssocialisme met Jan Schaefer als aansprekend boegbeeld. Ook het tijdperk van dualisering, burgerparticipatie en decentralisatie waarin we nu zitten, heeft weer nieuwe 'grensverleggers' opgeleverd, waarvoor ook in het buitenland (zie het burgemeestersboek van Benjamin Barber) belangstelling is. Tot besluit werpt de auteur een blik op de toekomst. De huidige globale problemen waarmee ook gemeenten worden geconfronteerd, vragen om lokale bestuurders die een goede mix bezitten van politiek leiderschap, nieuw burgerlijk leiderschap, inspirerend opdrachtgeverschap en goed rentmeesterschap.

\section{Inleiding}

Het thema van het VNG-jaarcongres 2018 in Maastricht is 'Over grenzen'. Daarmee worden lokale bestuurders bedoeld die voor het oplossen van knellende, complexe maatschappelijke problemen grenzen durven te verleggen. Daarvoor is het nodig om bij de samenwerking binnen en tussen gemeenten, tussen overheden en vakdisciplines, met het buitenland, met het bedrijfsleven en maatschappelijke instellingen en last but not least met de inwoners bestaande grenzen te overschrijden. In dit essay bekijk ik hoe lokale bestuurders dat in het verre en meer

* $\quad$ Dit essay is een themabijdrage voor het VNG-jaarcongres op 26 en 27 juni 2018 in Maastricht met als thema 'Over grenzen'. De auteur bedankt Bas Denters (Universiteit Twente), Marcel Boogers (BMC/Universiteit Twente) en Rogier van der Wal (VNG/Universiteit Leiden) hartelijk voor hun steun bij de totstandkoming van dit essay. 
recente verleden hebben gedaan. Wellicht kunnen we daarvan nog wat leren voor de toekomst. Voor het gemak deel ik mijn geschiedenis van het grensverleggend lokaal bestuur in vijf perioden in. ${ }^{1}$ Deze indeling is niet helemaal willekeurig gekozen, omdat het lokaal bestuur in deze perioden met verschillende problemen en uitdagingen te maken had. De eerste periode vóór 1910 is die van het progressief liberalisme en het door de gemeente verschaffen van nutsvoorzieningen als water, gas, elektriciteit en openbaar vervoer. De tweede periode loopt van 1910 tot 1940 . In deze periode neemt het wethouderssocialisme het voortouw bij het realiseren van een verzorgingsgemeente, die vooruitloopt op de verzorgingsstaat van na de Tweede Wereldoorlog. De derde periode (vanaf 1940 tot 1970) start met de bezetting en de wederopbouw en gaat verder met het, mede door de hoge economische groei gemotiveerde, streven naar cityvorming. De stadsvernieuwing in de vierde periode (van 1970 tot 2000) met haar streven naar kleinschaligheid vormde hierop een reactie, maar ging geleidelijk over in een breder proces van stedelijke ontwikkeling (fysiek, economisch en sociaal). Waar inspraak het toverwoord was voor de betrokkenheid van de burger bij het lokaal bestuur in de vierde periode, is dat in de vijfde en laatste periode (vanaf 2000 tot nu) burgerparticipatie. Van de burger wordt verwacht dat hij op alle fronten meedoet in het lokaal bestuur dat door dualisering en decentralisatie goed op zijn taken berekend zou moeten zijn.

Per periode zal ik op zoek gaan naar spraakmakende lokale bestuurders die bestaande grenzen durfden te verleggen. ${ }^{2}$ In de Nederlandse situatie is traditioneel vaak een belangrijke rol weggelegd voor wethouders, maar ook burgemeesters, raadsleden en ambtenaren (zoals gemeentesecretarissen en directeuren) kunnen een grensverleggende rol spelen. Ik zal daarbij ook letten op de voor hun grensverleggende rol relevante persoonlijke kenmerken en eigenschappen van deze spraakmakende lokale bestuurders. Bovendien worden grenzen niet in een bestuurlijk vacuüm verlegd: andere actoren in de omgeving van deze 'grensverleggers' kunnen een stimulerende of juist een remmende invloed hebben. Ook de omstandigheden hebben invloed op de manier waarop en de mate waarin grenzen kunnen worden verlegd. Daarbij kan bijvoorbeeld worden gedacht aan de poli-

1 Zie voor varianten op deze indeling in perioden Van den Berg en Boogaard (2018) en Reussing e.a. (2018). Van den Berg en Boogaard onderscheiden in hun geschiedenis van de gemeenteraad vijf perioden: (a) notabelenbestuur (1851-1895), (b) politisering en eerste ronde wethoudersocialisme (1895-1931), (c) professionalisering en technocratisering (1931-1970), (d) politisering en tweede ronde wethoudersocialisme (1970-2000), en (e) dualisering, decentralisatie en de prijs van half werk (2000 tot nu). Een andere variant hierop (die is toegespitst op de rol van de raad bij regionale samenwerking) is de indeling van Reussing e.a. die de twee eerste perioden onder de oude Gemeentewet (1851-1931) samenvoegen en daarnaast drie andere perioden onderscheiden: 1931-1950 (onder de herziene Gemeentewet), 1950-1985 (onder de nieuwe Wet Gemeenschappelijke Regelingen) en 1985 tot nu (onder de herziene WGR).

2 Voor mijn essay maak ik zo veel mogelijk gebruik van beschikbare (auto)biografieën en andere boeken. Waar nodig vul ik dit aan met publiek toegankelijke gegevens uit digitale bronnen als Wikipedia, Parlement \& Politiek en het (via Resources Huygens ING ook digitaal beschikbare) Biografisch Woordenboek van Nederland. Zie voor een historisch overzicht van de ontwikkeling van het gemeentelijke takenpakket Veldheer (1994a en 1994b). 
tieke cultuur en de politieke krachtsverhoudingen in een gemeente. Tot besluit van het essay ga ik in op de vraag wat deze spraakmakende lokale bestuurders ons nu nog te zeggen hebben en wat we van hen kunnen leren. Wat zijn tegenwoordig de maatschappelijke problemen en uitdagingen die vragen om grensverleggend bestuur? Welke eisen stelt dat aan onze huidige lokale bestuurders waarvan we verwachten dat ze nieuwe perspectieven bieden en concrete oplossingen aandragen voor deze problemen en uitdagingen? Hoe kunnen zij succesvol opereren in onze complexe en dynamische netwerksamenleving?

\section{Periode vóór 1910: progressief liberalisme en gemeentevoorzieningen}

Omdat het lokaal bestuur ook wordt beïnvloed door internationale ontwikkelingen start ik de beschrijving van de eerste periode in het buitenland in Groot-Brittannië. Daar waren de gevolgen van de industriële revolutie en de individualistische invulling van het liberalisme eerder merkbaar dan in Nederland. Dit leidde tot een beweging van progressieve liberalen naar een actiever overheidsingrijpen en het door de gemeente verschaffen van publieke nutsvoorzieningen die bekend stond als het 'municipal socialism'. 'Municipal socialism refers to the ownership and operation of public utilities, such as gas, electricity, streetcars, and water, by municipal governments rather than private enterprises.' Deze term werd het meest in verband gebracht met het optreden van Joseph Chamberlain die als burgemeester van Birmingham (1873-1876) het middelpunt was van veel hervormingsactiviteit in korte tijd (Maver, 2000: 153). Chamberlain had een grote charismatische aantrekkingskracht en hervormde in de stad Birmingham de stedelijke gezondheidsdienst, liet krottenwijken afbreken, pleitte vurig voor een algemene leerplicht en zorgde ervoor dat de Universiteit van Birmingham in 1900 kon worden opgericht. Hij plaatste ook de gas- en watervoorziening onder het gemeentelijk toezicht en eigendom. ${ }^{3}$ Deze veranderingen waren van grote betekenis voor de manier waarop deze voorzieningen in de rest van het land tot stand kwamen. In 1876 werd hij gekozen tot lid van het Britse Lagerhuis. Hij werd daar al spoedig een van de belangrijkste kopstukken onder de liberalen. Hij koos voor een linkse koers, streefde naar hervormingen die soms een socialistisch karakter hadden. De liberale partij ontwikkelde zich onder Chamberlain tot een brede volkspartij. Overigens zocht hij na 1895 samenwerking met de conservatieven en ontpopte hij zich als een vurig verdediger van het Britse imperialisme.

Waar de gemeentelijke renaissance in Birmingham snel en spectaculair was, had het commitment in Glasgow voor het stedelijk activisme vanaf eind jaren tachtig

3 Cruciaal voor de ontwikkeling van de sociale houding van Chamberlain was de invloed van de 'civic gospel' van evangelische christenen. Vanaf de jaren dertig hadden de 'evangelicals' de meerderheid in de raad van Glasgow en startten met het verbeteren van de drinkwatervoorziening. Twee hervormingsgezinde predikanten uit deze groepering (George Dawson in 1847 en Henry Crosskey in 1869) vertrokken vanuit Glasgow naar Birmingham waar ze met een derde predikant (Robert Dale) de goddelijke missie van goed gemeentebestuur verkondigden (Gehrke, 2016: 25). Zie ook het hoofdstuk over Birmingham in de briljante studie van Asa Briggs (1968: 184-240) over Victorian Cities. 
Figuur 1 Spraakmakende grensverleggers in de periode voor 1910

\begin{tabular}{|l|l|l|l|l|l|}
\hline $\begin{array}{l}\text { Joseph } \\
\text { Chamberlain } \\
\text { (Birmingham) }\end{array}$ & $\begin{array}{l}\text { Robert } \\
\text { Crawford } \\
\text { (Glasgow) }\end{array}$ & $\begin{array}{l}\text { James } \\
\text { Marwick } \\
\text { (Glasgow) }\end{array}$ & $\begin{array}{l}\text { Wim } \\
\text { Treub } \\
\text { (Amsterdam) }\end{array}$ & $\begin{array}{l}\text { Carel } \\
\text { Gerritsen } \\
\text { (Amsterdam) }\end{array}$ & $\begin{array}{l}\text { Willem } \\
\text { van Leeuwen } \\
\text { (Amsterdam) }\end{array}$ \\
\hline & & & &
\end{tabular}

een langduriger karakter. Daar werd het in verband gebracht met het optreden van verschillende raadsleden en ambtenaren die niet de charismatische aantrekkingskracht van Chamberlain cultiveerden. In Glasgow had de stijl van Birmingham meer invloed dan de inhoud. Een belangrijke pionier van het 'municipal socialism' in Glasgow (in navolging van zijn politieke mentor Chamberlain) was het ijverige liberale raadslid Robert Crawford die het initiatief nam tot de bouw van het volkspaleis, het People's Palace of Arts, in 1891 (Maver, 2000: 153-154). Hij was een van de invloedrijkste raadsleden in deze periode al schopte hij het nooit tot burgemeester (Lord Provost). Voor het Amerikaanse publiek schetste hij (Crawford, 1906) de ontwikkeling van het onder gemeentelijk bestuur brengen van publieke nutsvoorzieningen in Glasgow die daarvóór in private handen waren: water in 1855, gas in 1869, elektriciteit in 1890 en openbaar vervoer in 1894 (eerst nog de paardentram, maar een jaar later werd al besloten tot de invoering van de elektrische tram). Met veel gevoel voor publiciteit beschreef hij de zegeningen van het gemeentelijke beheer van deze nutsvoorzieningen en het efficiënte bestuur van deze gemeentebedrijven door de raadscommissies. ${ }^{4}$ Onder de noemer 'Greater Glasgow' voerde de stad in die periode een expansieve politiek richting haar buurgemeenten. De grote architect van deze politiek was de efficiënte gemeentesecretaris (town clerk) James Marwick. Hij cultiveerde het imago van excellentie door de bouw van een monumentaal stadhuis (met marmeren trappenhuizen) in 1888. Hij was in zijn tijd de hoogst betaalde ambtenaar in Groot-Brittannië en bleef in functie tot zijn pensionering op 77-jarige leeftijd in 1903. De reputatie van Glasgow, dat uitgroeide tot de tweede stad in het land na Londen, als model-gemeente had veel te danken aan zijn slimme greep op de public relations (Maver, 2000: 155-156). ${ }^{5}$

4 Crawford (1906: 3) wijst ook op de 'civic spirit' die bij de burgers van Glasgow uit iedere sociale klasse in ruime mate aanwezig is en gepaard gaat met trots ('civic pride') op de gemeentelijke ondernemingen en instituties.

5 Zijn boomlange (twee meter) zoon en naamgenoot James Marwick was de oprichter van een van de vier bedrijven die ten grondslag lagen aan het latere accountantsbureau KPMG (Klynveld Peat Marwick Goerdeler). 
Rik Reussing

In Nederland verenigden de progressieve liberalen zich in Amsterdam in de jaren tachtig onder de noemer 'radicalen'. De intellectuele aanvoerder van de radicalen was Wim Treub. Bij zijn aantreden als radicaal in de Amsterdamse gemeenteraad in 1889 weigerde hij echter een benoeming tot wethouder. Hij meende dat hij als wethouder toch niets zou kunnen uitrichten tegenover een raadsmeerderheid, die zijn denkbeelden op financieel terrein niet was toegedaan. Treub en zijn politieke vrienden stuurden aan op het in gemeente-exploitatie nemen van nutsbedrijven: de waterleiding, de gasvoorziening, de elektriciteitsvoorziening, de tram en de telefoon. De gemeenteraadsverkiezingen van 1893 stonden in het teken van de exploitatievorm van deze private monopoliebedrijven. Radicalen, katholieken en anti-revolutionairen verbonden zich om de conservatieve gemeenteburcht te veroveren. Het lukte hen om de meerderheid van de kiezers achter zich te krijgen, maar omdat tot 1919 steeds een derde deel van de raad werd gekozen, leidde dit nog niet tot een alternatieve meerderheid in de raad. Desondanks heeft Treub het wethouderschap aanvaard en in de drie jaar (1893-1896) dat hij wethouder van financiën en publieke werken was grote daden verricht. Hij stelde een gemeentelijke rekenkamer in en verscherpte het bouwtoezicht, maar de kroon op zijn werk was de 'naasting' van de monopoliebedrijven, al werd dat niet in alle gevallen nog tijdens zijn wethouderschap gerealiseerd: in 1895 de waterleiding, in 1896 de telefoon, in 1897 het gas en per 1 januari 1900 de Amsterdamse Omnibus Maatschappij, die vanaf 1875 de paardentram als vervanger van de omnibus in de stad exploiteerde (Van Esveld, 1958: 44-69). Vanaf die datum werd de exploitatie uitgevoerd door de Gemeentetram Amsterdam (GTA) en begon het proces van elektrificatie dat in 1906 is voltooid. In 1903 werd het elektriciteitsnet in beheer genomen en bestond er politieke consensus om dit te doen.

Ook andere lokale bestuurders waren betrokken bij het succes van Wim Treub. ${ }^{6}$ De radicale en flamboyante wethouder Treub en de in 1891 pas aangetreden conservatieve en wat stijve burgemeester Sjoerd Vening Meinesz (tussen 1881 en 1891 burgemeester van Rotterdam) leken op het eerste gezicht niet goed bij elkaar te passen. Toch kreeg hij snel waardering voor de daadkrachtige Treub. De overeenkomst tussen de beide mannen was dat ze betrokken waren bij hun werk en ze niets moesten hebben van vriendjespolitiek. Een positieve factor was dat de wethouders ook steeds meer als een team opereerden, vooral toen de liberaal en letterkundige Jan Nicolaas van Hall het college van B\&W kwam versterken. Een voorbeeld is de manier waarop Treub de twijfelende, en weinig daadkrachtige, liberale wethouder van publieke werken Louis Serrurier bijstond, die zich overigens bewust was van zijn eigen tekortkomingen. In 1895 vertrok Serrurier als wethouder, stapte Wim Treub zelf over van financiën naar publieke werken en nam de jurist Willem van Leeuwen (later werd hij ook burgemeester van Amsterdam) de portefeuille financiën over. In de politieke onderhandelingen met het gemeenteperso-

6 Treub had een actief en turbulent leven. Na zijn wethouderschap werd hij hoogleraar economie aan de Gemeentelijke Universiteit van Amsterdam. In 1905 was hij oprichter van de Vrijzinnig Democratische Bond en als minister van Financiën voor die partij loodste hij Nederland veilig door de Eerste Wereldoorlog. Als overtuigd liberaal bestreed hij de economische en politieke opvattingen van het marxisme en het socialisme (Treub, 1931; Slijkerman, 2016). 
neel over hun rechtspositie toonde Treub een grote mate van pragmatisme. Dat viel bij zijn rechtlijnige partijgenoot (raadslid voor de radicalen vanaf 1888) Carel Gerritsen in verkeerde aarde, waardoor hun onderlinge verhouding verslechterde (Slijkerman, 2016: 57-75). Als wethouder (1899-1902) is Gerritsen vooral bekend komen te staan als de wethouder die de Gemeentelijke Geneeskundige Dienst grondig hervormde. Doordat hij een eerste poging deed om meer greep te krijgen op de activiteiten van de medici in stad, bracht hem dit hevig in botsing met de medische beroepsgroep. Artsen zouden als medisch ambtenaren in vaste dienst van de gemeente gaan werken. Voor de artsen was dit onaanvaardbaar, omdat dit werd gezien als aantasting van het aanzien van het beroep door het verlies van autonomie. $^{7}$

De daadkrachtige en ietwat ijdele Willem van Leeuwen was zelf geen radicaal, maar hij kreeg als liberaal wethouder wel een steeds grotere verantwoordelijkheid voor het opkopen en reorganiseren van particuliere nutsbedrijven. Zijn zakelijke en gedreven houding bij deze transacties viel de omgeving op, waarmee hij de reputatie vestigde dat hij verantwoord met publieke middelen kon omspringen, hetgeen blijkbaar in die periode niet vanzelfsprekend was. In de ogen van Treub had Van Leeuwen twee karaktereigenschappen die aan zijn succesvolle carrière bijdroegen: hij stond voor zijn mening en schroomde niet er eerlijk voor uit te komen als hij zich had vergist. Door zijn heetgebakerdheid was zijn benoeming tot burgemeester van Amsterdam in 1901 niet onomstreden, maar anders dan anderen hadden voorspeld, bleek hij als burgemeester evenwichtig en doortastend op te treden. Deze daadkracht was ook vereist in een periode van grote sociale en economische veranderingen in Amsterdam. De bevolking was in snel tempo toegenomen, zodat er nieuwe stadswijken moesten komen. Onder het bewind van Van Leeuwen werd de stad naar alle kanten uitgebreid. Zo werd voor woningbouw ten zuiden van de stad het prestigieuze plan 'Berlage' vastgesteld, het op dat moment meest omvangrijke stedelijke plan voor de ruimtelijke ordening in Nederland. In 1905 werd in Amsterdam (op basis van de Woningwet uit 1901) de eerste bouwverordening vastgesteld, waarmee eisen konden worden gesteld over de kwaliteit van te bouwen woningen (Slijkerman, 2001: 172-173). ${ }^{8}$

Treub en zijn radicale partij waren in de minderheid in de Amsterdamse raad, maar hadden succes omdat zij het gemeentelijke beleid in overeenstemming wisten te brengen met de maatschappelijke behoefte. In het buitenland (vooral in Groot-Brittannië) was men daartoe al eerder overgegaan. De radicalen waren in die zin niet origineel, maar wel bijzonder daadkrachtig in hun navolging en uit-

7 Carel Victor Gerritsen was sinds 1884 (in een vrij huwelijk) getrouwd met Aletta Jacobs, de beroemdste Nederlandse vertegenwoordigster van de eerste feministische golf. Ze was ook de eerste vrouw in Nederland die succesvol een universitaire studie afrondde. Aletta Jacobs vestigde zich als huisarts in Amsterdam, waar ze gratis spreekuren hield en cursussen gaf. Als arts had ze een progressief standpunt ten aanzien van geboortebeperking.

8 In 1909 trad Van Leeuwen af als burgemeester van Amsterdam, onder meer uit onvrede over de kwaliteit van het stadsbestuur. Tussen 1914 en 1928 was hij vice-president van de Raad van State (Slijkerman, 2001: 170-180). Al in 1904 pleitte hij als senator voor de benoeming van wethouders van buiten de raad (Reussing, 2018: 68). 
voering van deze ideeën, en zonder het optreden van Treub was het beslist anders gelopen (Slijkerman, 2016: 76-77). Aan het begin van zijn raadslidmaatschap deed Treub al het baanbrekende voorstel de gemeentegronden voortaan in erfpacht uit te geven. Het voorstel kwam in mei 1895 in de gemeenteraad en werd in 1896 (het jaar van zijn afscheid) ingevoerd. Het stelsel maakte niet alleen een einde aan de grondspeculatie, maar zorgde er ook voor dat de waardevermeerdering van de grond aan de gemeente toekwam (Slijkerman, 2016: 37-38 en 73).

\section{Periode 1910-1940: wethouderssocialisme en verzorgingsgemeente}

Het uiteenvallen van de samenwerking binnen de radicale partij in Amsterdam ging samen met de opkomst van de sociaaldemocratie als nieuwe machtsfactor in de gemeente. Een cruciale rol bij deze overgang speelde journalist en politicus Pieter Lodewijk Tak die uit welgestelde ouders was geboren. ${ }^{9}$ Tak behoorde tot de initiatiefnemers die in 1888 radicale kiesvereniging 'Amsterdam' in het leven riep. Maar enige jaren later (in 1891) keerde hij de radicale beweging de rug toe, omdat volgens hem een duidelijk streven naar hervorming van de sociaaleconomische structuur van de maatschappij ontbrak. Hij zou gedurende een achttal jaren partijloos blijven (in die tijd maakte hij voor De Telegraaf verslagen van raadsvergaderingen), maar toen hij in 1899 eindelijk toetrad tot de SDAP zette hij meteen zijn stempel op de gemeentepolitiek van die partij door het leveren van gefundeerde kritiek op het gemeenteprogramma. Tak organiseerde ook de SDAP-raadsleden in 1902 en stelde hen een informatiebureau ter beschikking (Maas, 1974: 26-36; Maas, 1985: 36-49). In 1904 werd hij lid van de Amsterdamse gemeenteraad). ${ }^{10}$ Hij had ook een groot aandeel bij de totstandkoming van het SDAP-blad De Gemeente dat in 1907 (het jaar van zijn plotselinge overlijden) verscheen. Tak heeft via zijn veelzijdige activiteiten de basis gelegd voor de socialistische gemeentepolitiek waarvan Floor Wibaut de belangrijkste vertegenwoordiger werd (Borrie, 1973: 89-131). Niet Amsterdam, maar het rode bolwerk Zaandam leverde overigens met Jan Duijs (1912-1923) de eerste SDAP-wethouder en met Kornelis ter Laan (1914-1937) de eerste SDAP-burgemeester. Eiske ten Bos-Harkema werd in 1923 de eerste vrouwelijke wethouder van de SDAP in de Drentse gemeente Gasselte (Kalk, 2005). ${ }^{11}$

Floor Wibaut (1859-1936) was geboren in Vlissingen, maar bracht net als Tak het grootste deel van zijn jeugd door in Middelburg. Ook hij kwam uit een relatief welgestelde familie en wist als directeur van een internationale houthandel een

9 Tak had een indrukwekkende journalistieke loopbaan en een eminente schrijfstijl die hem achtereenvolgens verbond aan de Middelburgse Courant, De Amsterdammer, De Nieuwe Gids, De Kroniek en Het Volk.

10 Vakbondsman Henri Polak was de eerste sociaaldemocraat die zitting had in de Amsterdamse gemeenteraad, van januari 1903 tot april 1906. Hij was overigens ook de eerste sociaaldemocraat in de Eerste Kamer.

11 De liberalen hadden overigens al vanaf 1919 een vrouwelijke wethouder (dat was Willy HofmanPoot in het Noord-Hollandse Oostzaan), evenals de katholieken (Stiena Ruypers-Erens in het Limburgse Valkenburg). 
aanzienlijk vermogen te verdienen en financieel zelfstandig te worden. Voor zijn werk als houthandelaar was hij wekelijks in Amsterdam. Hij werd daar eerst gegrepen door het radicalisme en later door het socialisme (in 1891 vertaalde hij het manifest van de 'Fabian Society' in het Nederlands), al werd hij pas in 1897 lid van de SDAP. Hij vestigde zich in 1904 definitief in Amsterdam, werd in 1907 raadslid en in 1914 wethouder. ${ }^{12}$ Hij was wethouder van 1914 tot 1927 en 1929 tot 1931. Op twee verschillende terreinen liet hij zich gelden als grensverleggend bestuurder. Tot 1921 maakte hij indruk als wethouder op het terrein van de volkshuisvesting. Die periode kenmerkte zich door een krachtdadige bevordering van de woningbouw (waardoor hij de bijnaam 'Wibaut de Machtige' kreeg) door optimaal gebruik te maken van de mogelijkheden in de Woningwet van 1901, onder meer via het binnenhalen van veel rijkssubsidies (Borrie, 1987: 121-129). Vanaf 1919 beheerde hij ook de portefeuille financiën. In zijn financieel beleid ging hij uit van drie grondbeginselen: een sluitende gemeentebegroting, progressiviteit van de belastingen en doelmatigheid van de gemeentelijke uitgaven. Wat betreft de financiering van buitengewone uitgaven stond hij op het (omstreden) ruime standpunt dat de gemeente mocht lenen voor alle duurzame nuttige uitgaven die aan de gemeenschap langer dan één jaar diensten bewijzen. (Borrie, 1987: 152-160). Hij was ook een grensverlegger als voorzitter van de Internationale Stedenbond, ${ }^{13}$ die hij in 1924 via een congres in Amsterdam nieuw leven inblies (Couperus, 2009: 130-135). Enkele dagen later bekleedde hij ook het voorzitterschap van het Internationaal Stedenbouwkundig Congres (Kaal, 2008: 91).

Op de portefeuille volkshuisvesting werd Wibaut in 1921 opgevolgd door zijn partijgenoot Monne de Miranda (hij was sinds 1911 SDAP-raadslid en vanaf 1919 wethouder). Hij zou met enkele onderbrekingen wethouder blijven tot september 1939. De Miranda was geboren in een arme Jodenbuurt en door zelfstudie opgeklommen tot vakbondsbestuurder. Hij was een zeer gedreven politicus die een groot aantal bekende projecten op zijn naam heeft staan. Hij was betrokken bij het levensmiddelenbeleid (hij was initiatiefnemer tot de Centrale Markthallen), de woningbouw en grote werkgelegenheidsprojecten (zoals het Amsterdamse Bos en het Flevopark). Door de bouw van een aantal zwembaden werd hij populair: het 'Amstelparkbad' is later omgedoopt tot het 'De Mirandabad'. Zijn ambitieuze plan uit 1926 voor de bouw van tuinstad Gooistad op de hei ten behoeve van Amsterdamse arbeiders, strandde op het massieve verzet van de mensen in Het Gooi. Wibaut was de grote leermeester van De Miranda op het terrein van de gemeentepolitiek. De vruchtbaarste periode van het wethouderssocialisme lag in

12 Over Wibaut is al veel geschreven. De belangrijkste bronnen zijn de autobiografie (Wibaut, 1936), het proefschrift van Maas (1974) en de uitgebreide biografieën van Borrie (1987) en De Liagre Böhl (2013). Een opmerkelijk detail is dat Wibaut in 1896 als correspondent van De Telegraaf de Socialistische Internationale in Londen bezocht. Wibaut bleef zich marxist noemen, maar hij sloot in zijn gemeentepolitiek meer aan bij de Fabian Society onder leiding van Sidney en Beatrice Webb, die op hun beurt weer waren beïnvloed door Joseph Chamberlain.

13 Het eerste congres van de Internationale Stedenbond (IULA) vond plaats in 1913 in Gent (België), in hetzelfde jaar organiseerde Gent de wereldtentoonstelling. Door de Eerste Wereldoorlog werden de contacten abrupt verbroken. 


\section{Figuur 2 Spraakmakende grensverleggers in de periode 1910-1940}

\begin{tabular}{|l|l|l|l|l|l|}
\hline $\begin{array}{l}\text { Floor } \\
\text { Wibaut } \\
\text { (Amsterdam) }\end{array}$ & $\begin{array}{l}\text { Monne } \\
\text { de Miranda } \\
\text { (Amsterdam) }\end{array}$ & $\begin{array}{l}\text { Emanuel } \\
\text { Boekman } \\
\text { (Amsterdam) }\end{array}$ & $\begin{array}{l}\text { Willem } \\
\text { Drees } \\
\text { (Den Haag) }\end{array}$ & $\begin{array}{l}\text { Arie } \\
\text { Heijkoop } \\
\text { (Rotterdam) }\end{array}$ & $\begin{array}{l}\text { Arie } \\
\text { de Zeeuw } \\
\text { (Rotterdam) }\end{array}$ \\
\hline & & &
\end{tabular}

de jaren twintig, toen zij beiden een sterk stempel drukten op het bestuur van de stad, waarbij Wibaut zonder twijfel als eerste man optrad. Het verschil in afkomst en opleiding trad niet alleen duidelijk naar voren in de politiek en het gemeentebestuur, maar ook in de verhouding tot de buitenwacht. Wibaut was de sociaal bewogen magistraat, De Miranda de partijman die onparlementair taalgebruik niet schuwde. Hij irriteerde daarmee zijn politieke tegenstanders, werd het slachtoffer van een antisocialistische hetze met bedenkelijke antisemitische aspecten en werd uiteindelijk gedwongen zijn ontslag te nemen als wethouder (Borrie, 1993: 408-409). ${ }^{14}$

Van de vooroorlogse SDAP-wethouders in Amsterdam verdient naast Wibaut en De Miranda ook Emanuel Boekman speciale vermelding. Hij was politicus, demograaf, statisticus, schrijver en typograaf, maar staat vooral bekend als bestuurder en wethouder en voorvechter van kunstbeleid door de overheid. Vanaf 1921 tot zijn dood in 1940 was hij voor de SDAP lid van de gemeenteraad van Amsterdam. In 1931 werd hij wethouder van onderwijs en kunstzaken tot 1933, en opnieuw van 1935 tot $1940 .{ }^{15}$ De economische situatie van Nederland in de jaren dertig vormde voor Boekman bij zijn aantreden als wethouder in 1931 een buitengewoon ongunstig uitgangspunt voor het voeren van een vooruitstrevend onderwijsbeleid. De bezuinigingen van het Rijk hadden directe gevolgen voor de onderwijsuitkeringen aan de gemeenten. Op het gebied van kunstzaken voerde hij een actief beleid, gericht op het toegankelijk maken van theater, muziek en beeldende kunst voor de arbeidersklasse, waarbij in het bijzonder de vrijheid van de kunst (vooral waar dat het toneel betrof) door hem krachtig werd verdedigd. In 1939 promoveerde hij aan de Universiteit van Amsterdam bij Nicolaas ter Veen op het

14 In 1939 werd De Miranda in een lastercampagne die 6 januari 1939 met een artikel in De Telegraaf startte, valselijk beschuldigd van corruptie bij een erfpachtuitgifte, wat uiteindelijk leidde tot zijn aftreden op 5 september 1939. Zijn verweerschrift Pro Domo zou het grote publiek nooit bereiken en werd pas in 1997 gepubliceerd. Op 3 november 1942 kwam een eind aan zijn leven toen hij in kamp Amersfoort door landgenoten op gruwelijke wijze werd vermoord.

15 Op 15 mei 1940, de dag van de Nederlandse capitulatie voor de nazi-Duitse overmacht, maakte hij met zijn vrouw en met het bevriende gezin van de socialistische econoom Bob van Gelderen een eind aan zijn leven. 
proefschrift Overheid en kunst in Nederland, waarin hij een toekomstig cultuurbeleid voor het Rijk en voor de gemeenten beschreef, dat onder meer kunstverbreiding onder het volk en opdrachten voor kunstwerken bij nieuwbouw inhield (zie o.a. Borrie, 1989).

In de hoofdstad waren de Amsterdamse sociaaldemocraten in de gemeentepolitiek in het interbellum de dominante machtsfactor. ${ }^{16}$ Alhoewel de SDAP geen raadsmeerderheid had en hun wethouders scherpzinnig tegenspel van het jonge RKSP-raadslid Carl Romme kregen, moest ook Romme constateren dat de SDAP'ers in het college onmisbaar waren (zie Bosmans, 1991: 125-209). In Den Haag (waar de liberalen sterk waren) had de SDAP een minder dominante positie en dat tekende het wethouderschap van Willem Drees. Hij werd in 1919 wethouder van sociale zaken, maar verruilde die portefeuille in 1931 voor financiën en openbare werken. In de gemeentepolitiek kreeg bij hem de nuchterheid de overhand op de bevlogenheid. Door de samenwerking met vertegenwoordigers van andere politieke richtingen in gemengde colleges ontdekte hij dat het bedrijven van verstandige politiek bestond uit het sluiten van compromissen (De Liagre Böhl, 2014: 137-138). Ook dan blijft het mogelijk om bestuurlijke grenzen te verleggen, maar alleen niet zover als aanvankelijk bedoeld. Illustratief in Den Haag is de discussie over het vraagstuk van het Haagse tramnet. Na afloop van de concessie aan de particuliere Haagse Tramwegmaatschappij (HTM) in 1927 rees de vraag hoe de exploitatie moest worden voortgezet. De SDAP wilde er het liefst een overheidsbedrijf van maken, maar moest door complicerende omstandigheden genoegen nemen met het collegevoorstel een 'gemengd bedrijf' op te richten, deels overheids- en deels particulier bedrijf. Wel slaagde Drees er in bij de HTM-directie belangrijke toezeggingen af te dwingen op het gebied van de arbeidsvoorwaarden. Hij voerde de onderhandelingen in eendrachtige samenwerking met de liberale wethouder Pieter Droogleever Fortuyn ${ }^{17}$ en de anti-revolutionaire wethouder Hubertus de Wilde ${ }^{18}$ (Gaemers, 2006: 279-284).

In Rotterdam waren in 1919 Arie Heijkoop en Arie de Zeeuw (in november 1918 hadden zij nog een belangrijke rol gespeeld bij de mislukte revolutiepoging van Troelstra) de eerste rode wethouders: Heijkoop op het gebied van de volkshuisvesting, De Zeeuw van onderwijs en kunsten. Met name voor Heijkoop (hij was

16 In de periode 1921-1941 was de anti-revolutionair Willem de Vlugt (zie hierover ook het proefschrift van Kaal uit 2008) burgemeester van Amsterdam. Ook hij had een betere verhouding met Wibaut dan met De Miranda en speelde geen glorieuze rol in de kwestie-De Miranda, omdat hij hem tijdens het erfpachtschandaal liet vallen.

17 Pieter Drooglever Fortuyn werd als wethouder in Den Haag en als burgemeester van Rotterdam (vanaf 1928) door politieke tegenstanders zeer gerespecteerd. Als VNG-voorzitter was hij ook een krachtig strijder voor de gemeentelijke autonomie. In 1937 verrichtte hij de aftrap voor de eerste wedstrijd in de Kuip, nadat hij in 1925 ook al met een aftrap het Zuiderpark Stadion in gebruik had gesteld. Hij schreef in 1923 een boek over het bestuur van grote gemeenten.

18 Hubertus de Wilde was tussen 1933 en 1939 voor de ARP minister van Binnenlandse Zaken en later minister van Financiën in diverse kabinetten onder leiding van Hendrik Colijn. Gerrit van Poelje (1963: 13) noemt hem en Pieter Droogleever Fortuyn in het rijtje krachtige wethouders met Wim Treub en Floor Wibaut. Met o.a. Gerrit van Poelje en Willem Drees was hij sinds 1921 ook redactielid van het academische tijdschrift Gemeentebestuur. 
eerder medewerker van het legendarische SDAP-raadslid Hendrik Spiekman) was de strijd tegen de alkoven en voor frisse, zonnige arbeiderswoningen een heilige oorlog. Door zijn impulsieve invallen, die vaak irriterend en provocerend waren, maakte hij het zijn tegenstanders ook niet echt gemakkelijk. Na het aannemen van de alkoofmotie, met steun van de liberalen en de confessionelen, bleven de Aries twee jaar (1921-1923) buiten het college (De Ruyter-de Zeeuw, 1987: 102-103). Tussen 1927 en 1932 en tussen 1935 en 1942 (ook locoburgemeester) was De Zeeuw wethouder van financiën en bedrijven. In de tweede helft van de jaren twintig vond hij ook zijn stijl en vorm als socialistisch gemeentebestuurder. Hij had geleerd van zijn positieve en negatieve ervaringen en was meer geneigd tot constructieve samenwerking. Ondanks pogingen van politieke tegenstanders lieten de beide Arie's zich niet tegen elkaar uitspelen en ondanks verschillen in levensopvatting en wijze waarop ze hun idealen uitdroegen (Heijkoop was een vakbondsman, De Zeeuw een onderwijsman) bleven ze onderling vrienden (De Ruyter-de Zeeuw, 1987: 109). Heijkoop, die door het gebruik van beton in de woningbouw de bijnaam 'Arie Beton' kreeg, zou al in 1929 overlijden aan longemfyseem. Als derde belangrijke SDAP-wethouder trad in 1931 Johan Brautigam aan op sociale zaken, vanaf 1935 op openbare werken en volkshuisvesting. Na het aftreden van burgemeester Pieter Oud in 1941 installeerde Arie de Zeeuw als waarnemend burgemeester de nationaalsocialistische burgemeester Müller. Hij hield daarbij een toespraak waarin hij getuigde van zijn democratische gezindheid en liet het omhangen van de ambtsketting over aan een bode. De meningen over het optreden van De Zeeuw waren echter sterk verdeeld en na de oorlog sprak de Centrale Ereraad zijn afkeuring hierover uit. ${ }^{19}$

Ook in andere steden waren in de tijd van het (eerste) wethouderssocialisme SDAP-wethouders actief (en in hun voetsporen wethouders van andere politieke partijen) die een bijdrage leverden aan het ontstaan van een verzorgingsgemeente als voorloper van de verzorgingsstaat, al hadden ze daarbij in de jaren dertig te maken met de gevolgen van de wereldwijde economische crisis. In Haarlem kunnen de namen van Jan Gerritsz ${ }^{20}$ en Marius Reinalda (zie Borrie, 2005: 93-132) worden genoemd. In andere Nederlandse steden, zoals het overwegend katholieke Nijmegen, vonden geen socialistische experimenten plaats, maar was er wel een sociale gemeentepolitiek richting het gemeentepersoneel, gemeentelijke werklozenzorg, gemeentelijke armenzorg, onderwijs, volkshuisvesting en gezondheidszorg (Maas, 1974: 301-447). terugkeren als bestuurder voor de Rotterdamse SDAP en haar opvolger de PvdA (De Ruyter-de Zeeuw, 1987: 173-197).

20 Jan Gerritsz voerde in 1909 al de redactie over de eerste Nederlandse bundel met diverse door verschillende deskundigen (zoals Dirk Hudig over het woningvraagstuk en Salomon de Monchy over het gemeentelijk grondbedrijf) geschreven hoofdstukken over modern gemeentebeheer. Hij was wethouder van Haarlem van 1928 tot aan zijn dood in 1936. Hij werd bekend om zijn strijd tegen de werkloosheid van de jaren dertig, stond aan de wieg van het Schoterbos en was een van de motoren achter de ontwikkeling van Schoten naar een moderne stadswijk. 


\section{Periode 1940-1970: bezetting, wederopbouw en cityvorming}

De Duitse inval in 1940 en de daaropvolgende bezetting betekende een radicale breuk met het verleden. In Zaandam werd SDAP-burgemeester Joris in 't Veld in maart 1941 gedwongen afstand te doen van zijn ambt doordat veel plaatsgenoten, net als in Amsterdam, meededen aan de Februaristaking. Na de capitulatie op 5 mei 1945 werd hij per fiets uitbundig binnengehaald en direct weer als burgemeester geïnstalleerd. Hij bleef aan tot zijn benoeming tot minister van wederopbouw en volkshuisvesting in 1948. Hij was een van de grondleggers van de bestuurswetenschappen in Nederland (hij was in 1929 in Leiden gepromoveerd op het onderwerp decentralisatie) en hij zou ook als burgemeester grensverleggend zijn door het inschakelen van wetenschappelijke kennis bij het bestuur. In de maand van zijn gedwongen aftreden (maart 1941) verscheen een onderzoek naar samenwerking tussen en de mogelijke samenvoeging van Zaanse gemeenten onder leiding van de Amsterdamse sociograaf Nicolaas ter Veen (Ter Veen, 1941). Het onderzoek is uitgevoerd in opdracht van het college van B\&W van Zaandam, dat zelf buiten de herindelingsplannen van de provincie Noord-Holland voor de Zaanstreek was gebleven. Deze plannen betroffen alleen kleine gemeenten uit financiële motieven. Terug op zijn post in Zaandam pakte In 't Veld de zaken weer voortvarend aan met de oprichting van een sociografisch bureau voor het doen van onderzoek op sociaal, economisch en statistisch gebied. De eerste directeur werd in 1946 de pas bij Ter Veen in Amsterdam afgestudeerde sociograaf Aris van Braam, die pionierswerk verrichtte door het schrijven van een rapport over de toekomstige sociaaleconomische ontwikkeling van de gemeente Zaandam (Van Braam, 1949; Reussing e.a., 2018: 274).

We zagen hiervoor al dat in Rotterdam burgemeester Pieter Oud terugtrad uit zijn ambt. Hoewel zijn partij (VDB) geen zetel had in de raad werd hij als vrijzinnig democraat in 1938 verrassend tot burgemeester benoemd. ${ }^{21}$ Het begin van de Tweede Wereldoorlog bracht het bombardement van Rotterdam waarbij het centrum van de stad in puin werd gelegd. De bezetter zag in hem geen bedreiging en daarom kon Oud aanblijven als burgemeester. Snel na de capitulatie begon hij leiding te geven aan het opbouwwerk. In de gemeenteraad kwam hij regelmatig in botsing met het enige raadslid van de NSB. In juni 1941 liet hij deze door een paar politiemannen uit een vergadering verwijderen. Verschillende NSB'ers namen wraak door de burgemeester een maand later op zijn werkkamer te overmeesteren en hem vervolgens te fotograferen, nadat ze de burgemeester een schortje met daarop een pentagram (het symbool van de vrijmetselaars) hadden omgedaan. Dit was voor hem reden om zijn ontslag in te dienen. Op 7 mei 1945 arriveerde Oud weer op het stadhuis aan de Coolsingel in een open auto van de politie. Hij hervatte zijn burgemeesterstaak met kracht via de wederopbouw van de binnenstad en de havens, herstel van bestuur en ambtelijk apparaat, gezondma-

21 In 1946 ging Oud net als de meeste leden van de Vrijzinnig Democratische Bond (in 1995 opgericht door Treub) mee naar de 'doorbraakpartij' PvdA. In 1947 verliet hij deze partij weer na een meningsverschil over de koers van de nieuwe partij (en de socialistische symboliek) om in 1948 met Dirk Stikker de VVD op te richten. 


\section{Figuur 3 Spraakmakende grensverleggers in de periode 1940-1970}

\begin{tabular}{|l|l|l|l|l|l|}
\hline $\begin{array}{l}\text { Joris } \\
\text { in 't Veld } \\
\text { (Zaandam) }\end{array}$ & $\begin{array}{l}\text { Pieter } \\
\text { Oud } \\
\text { (Rotterdam) }\end{array}$ & $\begin{array}{l}\text { Gerhard } \\
\text { ter Pelkwijk } \\
\text { (Utrecht) }\end{array}$ & $\begin{array}{l}\text { Coen } \\
\text { de Ranitz } \\
\text { (Utrecht) }\end{array}$ & $\begin{array}{l}\text { Joop } \\
\text { den Uyl } \\
\text { (Amsterdam) }\end{array}$ & $\begin{array}{l}\text { Roel } \\
\text { de Wit } \\
\text { (Amsterdam) }\end{array}$ \\
\hline & & &
\end{tabular}

king van de financiële positie van de gemeente en de opbouw van het culturele en sociale leven. In deze tweede periode (die duurde tot 1952) lag het zwaartepunt van zijn burgemeesterschap. Hij had een krachtig gestel, was onvermoeibaar en had een ijzeren discipline (Borrie, 2000: 169-211). Zijn opvolger werd de PvdA'er Gerard van Walsum (van 1939 tot 1941 lid van de Rotterdamse raad voor de CHU). Als lid van de beginselprogrammacommissie in 1946-1947 gaf Van Walsum mede vorm aan de ideologische basis van de PvdA. Hij stond bekend als een regent ${ }^{22}$ met gevoel voor decorum, maar hij was door zijn integriteit, toewijding en bestuurskracht zeer gezien bij de Rotterdamse bevolking. De wederopbouw werd voltooid onder PvdA'er Wim Thomassen (1965-1974), die daarvoor burgemeester in Zaandam en Enschede was geweest. Hij speelde een belangrijke rol bij de ontwikkeling van de stad Rotterdam tot wereldhaven nummer één, maar in zijn optreden had hij altijd iets van de schoolmeester die hij vroeger geweest was.

Opmerkelijk is dat Utrecht in deze periode twee partijloze burgemeesters had, alleen tussen 1942 en 1945 onderbroken door een NSB-burgemeester. ${ }^{23}$ Gerhard ter Pelkwijk was burgemeester van Utrecht tussen 1934 en 1942 en tussen 1945 en 1948, Coen de Ranitz tussen 1948 en 1970. Gerhard ter Pelkwijk doorliep vanaf 1912 in dienst van de gemeente Den Haag verschillende functies en was nauw betrokken bij de huldiging van Koningin Wilhelmina op het Malieveld na de vergissing van Troelstra in 1918. In 1920 werd hij er tot gemeentesecretaris benoemd. Als burgemeester van Utrecht gaf Ter Pelkwijk in de crisisjaren impulsen aan werkgelegenheid door het Rijk te bewegen medewerking te verlenen aan een groot aantal projecten zoals het ophogen van de spoorlijnen bij het Centraal

De verpersoonlijking van het regentendom werd de Amsterdamse burgemeester Gijs van Hall (1957-1967). Hij wist in de roerige jaren zestig niet goed om te gaan met de gezagsproblemen die ontstonden door het optreden van de Provo-beweging en werd door de regering gedwongen met pensioen te gaan (Kennedy, 1995: 146-147).

23 Cornelis van Ravenswaaij had zich (naar eigen zeggen) niet uit politieke overtuiging in oktober 1940 aangemeld bij de NSB, maar om burgemeester te worden. In april 1941 werd hij burgemeester van Zaandam, in maart 1942 van Utrecht. Hier toonde hij zich een geharnast nationaalsocialist en bestrafte onder meer politieagenten die geen rol wensten te spelen bij het ophalen van Joden. Bij zijn proces erkende hij 'volkomen fout' te zijn geweest. 
Station en de bouw van Stadion Galgenwaard. In 1942 werd hij door de bezetter uit zijn functie ontheven en dook hij onder in Doorn, maar in 1945 keerde hij terug. Op het bordes van het stadhuis ontving hij onder luide toejuichingen de commandant van de bevrijdingstroepen. Onmiddellijk stortte hij zich met alle energie op het herstel van Utrecht. Tot zijn grote voldoening besloot de gemeenteraad op 26 februari 1948 een grondregeling met het Rijk aan te gaan voor de definitieve vestiging van het nieuwe Jaarbeurscomplex op het voormalige 'Suikerterrein'. Zijn karakter is omschreven als moedig, vaak onbuigzaam, doch sterk. Coen de Ranitz werd in 1948 tot veler verrassing (niet in het minst van hemzelf) als tamelijk onbekende ambtenaar benoemd tot burgemeester van de vierde stad van het land, nadat koningin Juliana de benoeming van Rolly ridder van Rap$\operatorname{pard}^{24}$ had verhinderd. Hoewel hij een 'jonker' was die met een deftig Haags accent sprak en ook regenteske trekjes had, wist hij bij alle lagen van de Utrechtse burgerij het vertrouwen te winnen. De Ranitz stond bekend vanwege zijn grote toewijding en goede contacten met de bevolking. Hij zette zich als ambassadeur van de stad in voor woningbouw, de ontwikkeling van het stationsgebied (Hoog Catharijne) en de uitbreiding van de universiteit. ${ }^{25}$ De beide Utrechtse burgemeesters belichamen de overgang die in deze periode plaatsvond van het beleid van wederopbouw naar het nieuwe beleid van planmatige en grootschalige cityvorming via krotopruiming en sanering. Door middel van het moderniseren van hele wijken (met name de oude binnensteden, de negentiende-eeuwse wijken en de vroegtwintigste-eeuwse wijken wilden bestuurders ruimte creëren voor kantoorpanden, winkelboulevards, royale toegangswegen en parkeergarages (De Liagre Böhl, 2012: 18).

Ook de Amsterdamse PvdA-wethouders in de jaren zestig Joop den Uyl (1962-1965) ${ }^{26}$ en Roel de Wit (1965-1970) hadden de stad gemodelleerd naar de grootschalige concepten die sterk leefden bij de machtige dienst publieke werken van de stad (De Liagre Böhl, 2012: 18), al zien we bij De Wit wel een duidelijke kentering. De bestuurders hadden in die tijd een groot vertrouwen in 'hun' technische diensten die werden gedragen door Delftse ingenieurs. Visie en beleid kwamen tot stand door discussie en beïnvloeding tussen bestuur en ambtenaren in de

24 Ridder Van Rappard, zoals hij gemeenzaam werd genoemd, was van 1939 tot 1971 burgemeester van Gorinchem, met een onderbreking tussen 1943 en 1945, omdat hij zich tegen de Duitse Arbeitseinsatz had gekeerd. Hij had een autoritaire stijl van leidinggeven, wat ook paste in zijn conservatieve maatschappijbeeld. Meermalen kwam hij in conflict met de gekozen wethouders, maar in en buiten Gorinchem genoot hij een zekere populariteit. Zie de recente biografie over Ridder van Rappard van de hand van Klaas Tammes (2018) die eerder onder het pseudoniem Nico van Abbenes vier politieke thrillers schreef die zich afspeelden in het lokaal bestuur.

25 Willem Michiels van Kessenich is bekend van zijn lange burgemeesterschap van Maastricht (1937-1967). Hij nam noodgedwongen tijdens de oorlogsjaren afstand van zijn ambt (1941-1944). Op 14 september 1944, de bevrijding van Maastricht, werd hij herbenoemd. Na de oorlog zette hij zich in om de oorlogsschade in Maastricht te herstellen. Verder werd onder hem de woningnood na de oorlog tegengegaan door woningen en woonwijken aan te laten leggen.

26 Joop den Uyl zat al sinds 1953 in de Amsterdamse gemeenteraad, was vanaf 1956 fractievoorzitter en was in die tijd ook directeur van de Wiardi Beckman Stichting, het wetenschappelijk bureau van de PvdA. In 1965 vertrok hij uit Amsterdam en werd minister van Economische Zaken in het kabinet Cals-Vondeling. 
wekelijkse stafbespreking (Van den Berg, 2016: 53). Zoals altijd stortte de econoom Joop den Uyl zich met alle energie en werkkracht waarover hij beschikte op zijn nieuwe baan als wethouder. Hij maakte ook reizen naar diverse steden (Stockholm, Marseille, Glasgow, Wenen) om zich daar te verdiepen in het openbaar vervoer, de grondpolitiek of de vormgeving van nieuwe wijken. Den Uyl had met publieke werken, stadsontwikkeling, economische zaken, havens en handelsinrichtingen een portefeuille van een omvang die daarna nooit meer is vertoond. Hij maakte zich de visie op de toekomst van de stad die uitging van grootschaligheid, planmatige uitbreiding van de stad en ruim baan voor het autoverkeer zonder reserves eigen, omdat hij die visie toen als modern en vooruitstrevend ervoer. Het 'Manhattan aan de Amstel' is er echter niet gekomen, omdat praktisch al deze plannen voor de binnenstad spoorloos zijn verdwenen in de la van Den Uyls opvolger (Bleich, 2008: 172-192). ${ }^{27}$ De bioloog Roel de Wit was sterk gericht op het scheppen van goede woonmilieus voor lagere inkomens en bij hem kregen de ruimtelijke ordening en de natuur alle aandacht. Als wethouder was hij een groot voorstander van het agglomeratiebestuur met Amstelveen, Diemen en OuderAmstel. Gedurende zijn wethouderschap werden de nadelige gevolgen van de groeiende welvaart steeds meer zichtbaar, zoals groeiende ruimteconsumptie, schaalvergroting en overvolle wegen. Dat de aaneengesloten stad aanzienlijk minder inwoners ging tellen, moest worden gecompenseerd door bevolkingsgroei in het gewest. Hij was een tegenstander van hoogbouw en had ook bedenkingen tegen grootschalige citybestemmingen in de binnenstad: dat betekende een forse wijziging met het beleid van zijn voorganger (Van den Berg, 2016: 55-57). ${ }^{28}$

\section{Periode 1970-2000: stadsvernieuwing, inspraak en stedelijke ontwikkeling}

Intussen voltrokken zich in de PvdA grote veranderingen door de machtsovername op landelijk niveau door Nieuw Links. ${ }^{29}$ De generatiewisseling betekende vooral een vernieuwing van de politieke cultuur. Voor de nieuwe generatie bestuurders vormden participatie, politisering en polarisatie het uitgangspunt (Depla \& Monasch, 1994: 260-263). In de stad Groningen was deze pressiegroep sinds eind jaren zestig actief onder leiding van de sociologiestudent Max van den Berg. Na de raadsverkiezingen van 1970 werd hij op 24-jarige leeftijd de jongste wethouder in Nederland. Omdat vrijwel de hele PvdA-fractie (onder leiding van

27 Alle megalomane grootschalige visioenen overziend is het volgens de Amsterdamse ambtenaar stadsontwikkeling Max van den Berg (2016: 31) misschien Den Uyls grootste verdienste geweest dat hij het grondbedrijf alle beschikbare landbouwgronden rond Amsterdam heeft laten opkopen, waarvan de stad tot op de dag van vandaag profiteert.

28 Vanaf 1949 was Roel de Wit werkzaam op het gebied van natuur- en landschapsbescherming. Van 1970 tot 1976 was hij burgemeester van Alkmaar en van 1976 tot 1992 Commissaris van de Koningin in Noord-Holland. Daarbij behield hij een aantal nevenfuncties op het gebied van natuurbescherming en ruimtelijke ordening.

29 Het optreden van Nieuw Links leidde tot het vertrek uit de PvdA van oudgedienden als Willem Drees en Gerard van Walsum. Anderen (zoals als Joop den Uyl) zouden hun politiek aanpassen aan de nieuwe koers. 
Figuur 4 Spraakmakende grensverleggers in de periode 1970-2000 (I)

\begin{tabular}{|l|l|l|l|l|l|}
\hline $\begin{array}{l}\text { Max van } \\
\text { den Berg } \\
\text { (Groningen) }\end{array}$ & $\begin{array}{l}\text { Jacques } \\
\text { Wallage } \\
\text { (Groningen) }\end{array}$ & $\begin{array}{l}\text { Ypke } \\
\text { Gietema } \\
\text { (Groningen) }\end{array}$ & $\begin{array}{l}\text { Jan van } \\
\text { der Ploeg } \\
\text { (Rotterdam) }\end{array}$ & $\begin{array}{l}\text { Han } \\
\text { Lammers } \\
\text { (Amsterdam) }\end{array}$ & $\begin{array}{l}\text { Jan } \\
\text { Schaefer } \\
\text { (Amsterdam) }\end{array}$ \\
\hline & & &
\end{tabular}

Jacques Wallage) inmiddels in handen was gekomen van Nieuw Links, kreeg hij veel beleidsterreinen in zijn portefeuille: cultuur, monumentenzorg, verkeer, openbare werken, openbaar vervoer, volkshuisvesting en stadsontwikkeling. Doordat Van den Berg weigerde om zich te onderwerpen aan de discipline van het collegiaal bestuur viel het oude afspiegelingscollege in 1972 en werd het eerste linkse meerderheidscollege (programmacollege) in een grote gemeente gevormd met Max van den Berg en Jacques Wallage (op de portefeuille onderwijs en cultuur, later onderwijs en verkeer) als belangrijkste wethouders. ${ }^{30}$ Tien jaar lang, van 1972 tot 1982, was er een progressief bestuur waarbij de inspraak hoogtij vierde. Op het stadhuis was het een komen en gaan van wijk- en actiegroepen en wanneer het erop aankwam koos het stadsbestuur voor de belangen van de inwoners en tegen het bedrijfsleven. Een van de meest controversiële ingrepen was de invoering van het Verkeerscirculatieplan in september 1977, waardoor het niet meer mogelijk was met de auto dwars door de binnenstad te rijden. Een jaar na de invoering van dit plan was in de ogen van Van den Berg zijn taak volbracht en nam hij afscheid als wethouder (De Liagre Böhl, 2012: 284-286).

In Amsterdam werd in 1970 de Nieuw Linkser Han Lammers de opvolger van Roel de Wit op de portefeuille stadsontwikkeling (naast kunstzaken). In zijn wethouderschap zou Lammers twee gezichten laten zien. Aan de ene kant zette hij de traditie voort van het modelleren van de stad naar de grootschalige concepten van publieke werken. Hoewel hij werd geconfronteerd met hardnekkige oppositie verbond hij zijn bestuurlijke lot aan het voltooien van het metrotracé. Het doorzetten van de sanering van de Nieuwmarktbuurt leidde in 1975 tot veldslagen tussen bewoners en de politie. Dat leidde er toe dat de gemeente afzag van een metronet voor de hele stad. De politieke verhoudingen in het Amsterdamse college waren intussen dermate bedorven dat Lammers zich in de zomer van 1976 gedwongen

30 Wallage bleef wethouder tot 1981, maar hij zou nog naar Groningen terugkeren als burgemeester (1998-2009). Hij ervoer dat ook hij (als geboren Groninger, studentenleider, fractievoorzitter en wethouder) zich moest aanpassen aan het feit dat Groningen een wethoudersstad is. Men wil een actieve burgemeester, maar het zwaartepunt in de aansturing van het ambtelijk apparaat en het debat met de raad ligt bij de wethouders (Wallage, 2018: 296-297). 
zag af te treden als wethouder (De Liagre Böhl, 2012: 58-59). Aan de andere kant was hij ook de wethouder die het Schetsplan voor een grote schoonmaak van de Jordaan, waarin nog slechts plaats was voor 13.000 bewoners in 4000 woningen, bij zijn aantreden als wethouder in juni 1970 onmiddellijk van tafel veegde. Hij besloot dat er spoedig een bestemmingsplan moest komen (dat gebeurde al in mei 1971) dat meer rekening hield met de wensen van de bewoners. De wijk zou worden hervormd, maar zonder haar karakter te verliezen. Overigens hield hij de touwtjes stevig in handen. Voor hem betekende medezeggenschap dat burgers adviezen mochten uitbrengen, maar niet dat ze via inspraak mochten meebeslissen over de buurtvernieuwing (De Liagre Böhl, 2012: 70-74). ${ }^{31}$

De renovatie van de Jordaan is een voorbeeld van het proces van stadsvernieuwing dat volgde op de periode van cityvorming. In dat nieuwe beleid kregen kleinschaligheid, prioriteit voor het wonen en een zo gering mogelijke verstoring van de bestaande sociale en stedenbouwkundige structuur de voorkeur boven verdere cityvorming, de bereikbaarheid van de stad voor auto's en grootschalige nieuwbouw van woningen (De Liagre Böhl, 2012: 7-9). Hierbij speelde PvdA-politicus Jan Schaefer een grote rol als aanjager. Eerst door als staatssecretaris in het kabinet Den Uyl (1973-1977) diverse subsidieregelingen in het leven te roepen, waaronder in 1977 de belangrijke Interim Saldo Regeling (ISR). ${ }^{32}$ In deze periode voerde hij ook regelmatig informeel overleg met de verantwoordelijke PvdA-wethouders in diverse grote en middelgrote steden. ${ }^{33}$ In 1978 keerde Jan Schaefer terug naar Amsterdam als wethouder woningzaken, stadsvernieuwing, bouw- en woningtoezicht en grondbedrijf en dat bleef hij tot 1986 (Hoeks, 2017: 200-271). Onder zijn leiding werd in deze tijd de stadsvernieuwing grondig aangepakt. De oude buurten werden opgeknapt en de bewoners werden bij de vernieuwing betrokken. Per buurt werd een specifieke projectgroep verantwoordelijk gemaakt, waarin ambtenaren de ruimte kregen om persoonlijk beslissingen te nemen en in te gaan op de wensen van buurtbewoners. De voorzitters van deze projectgroepen waren gemachtigd de directeuren van de betrokken diensten te passeren en direct contact te onderhouden met de wethouders. Schaefer was bij dit alles de spin in het web die het hele bouwproces beheerste (De Liagre Böhl, 2012: 62-63; uitgebreider De Liagre Böhl, 2010). Schaefer was een politicus die zich weinig aantrok van de heersende mores. Zo ging hij meestal in een spijkerpak gekleed en had hij

31 Na zijn aftreden als wethouder in Amsterdam werd Han Lammers landdrost van de Zuidelijke IJsselmeerpolders, burgemeester van Almere en Commissaris van de Koningin in de provincie Flevoland (De Liagre Böhl, 2015). In de tweejarige periode tussen Lammers en Schaefer werd zijn portefeuille overgenomen door Cees de Cloe, die later burgemeester werd van Hellevoetsluis en Lammers nog zou opvolgen als burgemeester van Almere.

32 De ISR en zeventien andere subsidieregelingen werden in 1985 vervangen door de Wet op de stads- en dorpsvernieuwing (WSDV), waarbij het beleid werd gedecentraliseerd naar gemeenten en provincies. Schaefer was aanvankelijk lid van de CPN. Als buurtactivist in de jaren zestig droeg hij bij aan het verhinderen van grootschalige sloop in De Pijp die de bouw van kantoren en luxe appartementen en de aanleg van een brede boulevard mogelijk moest maken.

33 Dat overleg werd gehouden in Utrecht en stond onder voorzitterschap van de Amsterdamse stedenbouwkundige Max den Berg, niet te verwarren met de gelijknamige Groningse wethouder (Van den Berg, 2016: 110-113). 
dikwijls geen stropdas om. Verder was hij een voorstander van helder taalgebruik in de politiek en in de ambtenarij. $\mathrm{Na}$ zijn wethoudersperiode keerde hij terug naar de Tweede Kamer, maar die terugkeer liep uit op een teleurstelling (Hoeks, 2017: 301-362).

De andere grote pionier van de stadsvernieuwing met een landelijke uitstraling was de Rotterdamse PvdA-wethouder Jan van der Ploeg (Van Agteren e.a., 1982). Hij was van 1953 tot 1967 lid van de gemeenteraad en tussen 1967 en 1974 wethouder onderwijszaken. In 1974 (tot 1982) verhuisde hij naar de portefeuille stadsvernieuwing en volkshuisvesting in het linkse programmacollege (de PvdA had voor het eerst een absolute meerderheid in de raad) onder leiding van de Nieuw Links burgemeester André van der Louw. De problemen in de negentiendeeeuwse wijken pakte hij voortvarend aan: binnen zes maanden had hij voor ruim 172 miljoen gulden in de revolutiebouwwijken 17.000 woningen opgekocht. De nieuwe koers kwam erop neer dat hij eigenaren (waaronder veel 'huisjesmelkers') niet meer bij het opknappen van de woningen betrok, maar buitenspel zette. De werkwijze bij de aanpak van de woningvoorraad was geleidelijk en gefaseerd, zodat bewoners in hun buurt konden blijven wonen en vervolgens naar de plek van hun oude woning konden terugkeren (De Liagre Böhl, 2012: 87-89). De projectgroepen waren gevestigd in de wijken zelf. Op het gebied van hun bevoegdheid en samenstelling ging Rotterdam verder dan andere steden. Onder Van der Ploeg hadden ze een zwaar bestuursmandaat (zij konden op eigen gezag besluiten nemen) en deden zij rechtstreeks aanbevelingen aan het college. Bovendien namen de wijkbewoners meer dan de helft van de vertegenwoordiging binnen de Rotterdamse projectgroepen. Andere steden boden wel inspraak, maar minder vergaand (De Liagre Böhl, 2012: 340-343). Hoewel de problemen van de oude Rotterdamse wijken energiek zijn aangepakt is zijn beleid achteraf niet een onverdeeld succes te noemen. Zijn nadruk op 'betaalbare' woningbouw liet geen ruimte voor de midden- en hogere inkomens in de stad. Het gevolg is dat de kwaliteit van de woningen weliswaar verbeterde, maar dat door de concentratie van groepen met lage inkomens en sociale problemen de kwaliteit van de woonomgeving in de oude wijken achteruitging. In 2002 leidde onvrede hierover tot de Fortuyn-revolutie en de opkomst van Leefbaar Rotterdam.

Ook in veel andere grote en middelgrote gemeenten stonden PvdA-wethouders in deze periode aan het roer bij de stadsvernieuwing, ieder met hun eigen accenten en wijze van optreden. In Leiden was het Cees Waal die vanaf 1974 (tot 1984) als lid van een links programmacollege de binnenstad vernieuwde. Zijn visie en daadkracht leidden tot weerstanden en ruzies, maar ook tot resultaten (Van Oosten, 2017). In Maastricht bekleedde John Wevers tussen 1974 en 1994 een brede portefeuille op het gebied van ruimtelijke ordening, volkshuisvesting, stadsvernieuwing en monumentenzorg. Voor zijn wethouderschap was hij actievoerder in de binnenstad van Maastricht. Wevers (onder zijn leiding werd het Céramique-terrein ontwikkeld) viel als wethouder op door de manier waarop hij vanuit een minderheidspositie in het college onverzettelijk en koppig zijn eigen zin doordreef als het om de gebouwde stad ging (Beek e.a., 1994; Wevers, 2016; Reussing: 2017b). 
Figuur 5 Spraakmakende grensverleggers in de periode 1970-2000 (II)

\begin{tabular}{|c|c|c|c|c|c|}
\hline $\begin{array}{l}\text { John } \\
\text { Wevers } \\
\text { (Maastricht) }\end{array}$ & $\begin{array}{l}\text { Cees } \\
\text { Waal } \\
\text { (Leiden) }\end{array}$ & $\begin{array}{l}\text { Adri } \\
\text { Duivesteïn } \\
\text { (Den Haag) }\end{array}$ & $\begin{array}{l}\text { Fons } \\
\text { Asselbergs } \\
\text { (Amersfoort) }\end{array}$ & $\begin{array}{l}\text { Margriet } \\
\text { Meindertsma } \\
\text { (Zwolle) }\end{array}$ & $\begin{array}{l}\text { Jan } \\
\text { Bugter } \\
\text { (Deventer) }\end{array}$ \\
\hline $\begin{array}{l}\text { IN } \\
\text { MAASTRICHI }\end{array}$ & & & & & \\
\hline
\end{tabular}

In Den Haag onderscheidde Adri Duivesteijn zich van zijn collega's in Amsterdam en Rotterdam door het onderstrepen van de culturele aspecten van de stadsvernieuwing en het inzetten van creatieve architecten bij het verbeteren van de woonomgeving om vernieuwingswijken, zoals de Schildersbuurt, van hun 'eentonige grauwheid' te verlossen (De Liagre Böhl, 2012: 117-118). Met John Wevers, Ypke Gietema in Groningen (met als belangrijk wapenfeit de nieuwbouw van het Groninger Museum) en Fons Asselbergs in Amersfoort (hij was verantwoordelijk voor de ontwikkeling van de nieuwe uitbreidingswijk Kattenbroek) behoorde hij tot de generatie van PvdA-bestuurders die in de jaren tachtig de architectuur tot een publieke zaak heeft gemaakt (Metz, 1993). Via de Werkgroep $5 \times 5$ wilde Adri Duivesteijn iets doen aan de kwaliteit van de volkshuisvesting in Nederland. Tot de ondertekenaars van het manifest behoorde ook de Zwolse wethouder (tussen 1985 en 1998 wethouder, vanaf 1993 tevens locoburgemeester) Margriet Meindertsma (Wevers, 2016: 289-290). Meindertsma was als wethouder verantwoordelijk voor de herstructurering van de naoorlogse wijk Holtenbroek, maar ook voor de ontwikkeling van de nieuwbouwwijk (Vinex-locatie) Stadshagen. Ze werd later, net als Adri Duivesteijn, lid van de Eerste Kamer. Beiden zouden als senator niet schromen standpunten in te nemen die afweken van de rest van de PvdA-fractie. $^{34}$

Rond 1985 waren de meest productieve jaren van de stadsvernieuwing voorbij en volgde de overgang naar een nieuw breder beleid van stedelijke ontwikkeling op fysiek, economisch en sociaal terrein. We zien in deze periode ook de opkomst van een nieuwe type wethouder. Na de opbouwers (Den Uyl, De Wit), de polarisatoren (Van den Berg, Wallage, Van der Ploeg, Lammers, Schaefer, Waal) en de managers (Wevers, Duivesteijn, Asselbergs, Gietema) zagen Depla en Monasch anno 1994 langzaam maar zeker binnen de PvdA een nieuwe generatie van netwerkers

34 Adri Duivesteijn trad in 1989 af als wethouder in Den Haag na een conflict met collega-wethouder Gerard van Otterloo over de inschatting van de risico's van de voorgestelde financiering van het nieuwe Haagse stadhuis. Hij was hierna directeur van het Nederlands Architectuurinstituut te Rotterdam (1990-1994), lid van de Tweede Kamer (1994-2006) en wethouder volkshuisvesting en ruimtelijke ordening van Almere (2006-2013). 
opkomen. Als een goed voorbeeld van zo'n netwerker noemden ze Jan Bugter die in de gemeente Deventer wethouder was (Depla \& Monasch, 1994: 267). In Deventer brak binnen het college van B\&W in het kader van de sociale vernieuwing het inzicht door dat er een andere aanpak nodig was. Jan Bugter was de drijvende kracht achter de Deventer Wijkaanpak, die werd ontwikkeld als reactie op de groeiende problemen op sociaal, economisch en fysiek gebied, in het bijzonder in de wijken met lage inkomens. Tegelijkertijd brak een van de ambtenaren van de gemeente Deventer, Marten Schuttert, in de ambtelijke organisatie een lans voor de nieuwe aanpak. Aan de toen voor Nederland zeer innovatieve wijkaanpak (gestart in 1992) is vorm gegeven door de stad gemeentedekkend op te delen in zes wijken, met in elke wijk een wijkteam, een wijkambtenaar, een wijkbudget en een wijkwethouder. Het zijn de bewoners die bepaalden wat er met het wijkbudget gebeurde (Hazeu e.a., 2005: 13-29). ${ }^{35}$ Het beleid van de coalitie van PvdA, CDA en VVD werd tot inzet gemaakt van de raadsverkiezingen van 1994 en zou in het nieuwe college met dezelfde samenstelling worden voortgezet, ondanks het verlies van een aantal zetels. ${ }^{36}$

\section{Periode na 2000: dualisering, burgerparticipatie en decentralisatie}

Het wijkgericht werken in Deventer is een voorbeeld van de omslag in de burgerparticipatie (zie Michels, 2018: 195) van inspraak (de eerste generatie) naar interactief beleid (de tweede generatie). In de nieuwe periode vanaf 2000 zal de nadruk binnen de burgerparticipatie komen te liggen op bewonersinitiatieven (de derde generatie) en op de dialoog tussen de gemeente en haar burgers via nieuwe deliberatieve vormen van burgerparticipatie. Andere belangrijke ontwikkelingen in deze periode zijn de invoering van de dualisering van het gemeentebestuur (in 2002 op basis van het rapport van de staatscommissie Elzinga) en de grootschalige decentralisatie van taken naar gemeenten in het sociaal domein. De periode vanaf 2000 ligt nog vers in ons geheugen. Pas over enige tijd is een goed en afgewogen oordeel mogelijk over wie de 'grensverleggers' in deze periode waren. Om een beeld te geven van de ontwikkelingen beperk ik me daarom tot mijn eigen woonplaats Enschede en tot drie bestuurders die in het buitenland (namelijk door Benjamin Barber in zijn burgemeestersboek) als spraakmakend en invloedrijk worden gezien.

De ontwikkelingen in Enschede worden gedomineerd door de gevolgen van de vuurwerkramp in de wijk Roombeek op 13 mei 2000. De vuurwerkramp leidde tot

35 Martin Knol was tussen 1994 en 2002 wethouder van Financiën in de gemeente Deventer en van 2003 tot 2010 in de gemeente Zwolle. Zie voor zijn ervaringen met het wijkgericht werken in Deventer: Knol, 2017: 39-40.

36 Het nieuwe college zou overigens al gauw in financieel zwaar weer komen, waardoor een van de drie wethouders van de PvdA in 1995 moest opstappen om verbreding van de coalitie mogelijk te maken via een D66-wethouder. De Deventer Wijkaanpak is in 2013 vervangen door WIJDeventer, dat wijkbewoners de ruimte geeft om initiatieven te ondernemen om de leefbaarheid te vergroten. De inwoners van Deventer beslissen zelf over een speciaal vastgesteld Meedoenbudget, dat is bedoeld om de leefbaarheid in hun wijk te verhogen. 
het aftreden van PvdA-wethouder Dick Buursink op 28 februari 2001, die als een van de weinigen de politieke verantwoordelijkheid voor de vuurwerkramp op zich nam na het uitkomen van het kritische rapport van de commissie-Oosting. ${ }^{37}$ Buursink bekleedde van 1994 tot 1998 de portefeuille stadsbeheer, van 1998 tot zijn aftreden de portefeuille leefbaarheid en wonen. In 1997 had Buursink, als wethouder verantwoordelijk voor onder meer milieubeheer, zijn paraaf gezet onder een bijlage bij een revisievergunning voor de vuurwerkfabriek S.E. Fireworks, waarbij hij afging op de deskundigheid van zijn ambtenaren, die op hun beurt moesten afgaan op de deskundigheid van een afdeling van het Ministerie van Defensie. Buursink bleef tijdens zijn wethouderschap (waarin hij het opnam voor goede fietsverbindingen vanuit de buitenwijken naar het centrum, het bevorderen van het openbaar vervoer en het terugdringen van de auto uit de binnenstad) een man van het volk: hij veranderde niet door de macht en bleef zichzelf, zeer toegankelijk, altijd de deur open, dialect sprekend als het kon, jargon bezigend als het nodig was. Jan Mans was in deze periode (1994-2005) burgemeester van Enschede. Hij had als burgemeester van Meerssen en Kerkrade de reputatie verworven van een doortastend bestuurder, maar zou in Enschede en de regio Twente aanvankelijk stuiten op de stroperigheid van de besluitvorming. De vuurwerkramp gaf hem de kans om zijn naam definitief te vestigen als effectief crisismanager. Hij stond de media na de ramp helder te woord en ging goed om met de nabestaanden. De verantwoordelijke diensten gaf hij daarbij alle ruimte bij het voorbereiden van besluiten, maar nam zelf de beslissingen en nam daar steeds de volle verantwoordelijkheid voor. $\mathrm{Na}$ zijn pensionering werd Jan Mans een populair waarnemend burgemeester in verschillende andere gemeenten (Vriesema, 2013).

Onder het burgemeesterschap van Mans werd ook de wederopbouw van de wijk Roombeek ter hand genomen. De nieuwe PvdA-wethouder voor stedelijke ontwikkeling en cultuur Roelof Bleker (2001-2010) gaf met directeur van het Projectbureau Wederopbouw Roombeek Peter Kuenzli en stedenbouwkundig supervisor Pi de Bruijn leiding aan een hecht team van professionele medewerkers uit alle disciplines. Zij zorgden ervoor dat de bewoners weer gingen geloven in de overheid door de snelheid waarmee beloften aan hen werden ingelost. ${ }^{38}$ In de wijk Roombeek werd ook volop geëxperimenteerd met nieuwe vormen van bewonersparticipatie en met diverse vormen van particulier opdrachtgeverschap. In 2007 nam Bleker als verantwoordelijk wethouder hiervoor namens de gemeente Enschede 'De Gouden Piramide' in ontvangst, de rijksprijs voor inspirerend opdrachtgever-

37 Dick Buursink (2002: 9-13) was als eerste lid van het college aanwezig op het stadhuis na de verwoestende klap, gevolgd door gemeentesecretaris Arjan van Gils, loco-burgemeester Eric Helder en burgemeester Jan Mans. Van 2007 tot 2011 was hij gedeputeerde van de provincie Overijssel voor cultuur, Europa en stedelijke netwerken.

38 In de woorden van programmamanager Ton van Snellenberg in een interview met U-Today op 25 april 2007. 


\section{Figuur 6 Spraakmakende grensverleggers in de periode na 2000}

\begin{tabular}{|l|l|l|l|l|l|}
\hline $\begin{array}{l}\text { Jan } \\
\text { Mans } \\
\text { (Enschede) }\end{array}$ & $\begin{array}{l}\text { Roelof } \\
\text { Bleker } \\
\text { (Enschede) }\end{array}$ & $\begin{array}{l}\text { Ed } \\
\text { Wallinga } \\
\text { (Enschede) }\end{array}$ & $\begin{array}{l}\text { Job } \\
\text { Cohen } \\
\text { (Amsterdam) }\end{array}$ & $\begin{array}{l}\text { Eberhard } \\
\text { van der Laan } \\
\text { (Amsterdam) }\end{array}$ & $\begin{array}{l}\text { Ahmed } \\
\text { Aboutaleb } \\
\text { (Rotterdam) }\end{array}$ \\
\hline & & &
\end{tabular}

schap. ${ }^{39}$ Innovatief was de gemeente Enschede ook op het terrein van het inzetten van wijkcoaches als nieuwe methodiek voor maatschappelijke ondersteuning. De wijkcoaches kregen ruime mandaten, vertrouwen en inspiratie om integraal te werken bij de aanpak van sociale problemen. Daarvoor heeft de gemeente afspraken gemaakt met alle partnerorganisaties. Bij het experiment in de krachtwijk Velve-Lindenhof, waarbij de wijkcoach optreedt als een sociaal huisarts in de eerstelijnszorg, toonde de verantwoordelijke PvdA-wethouder Ed Wallinga (2006-2014) met anderen, zoals de directeur Wijkontwikkeling, Zorg en Welzijn van de gemeente Hans Weggemans en de directeur van woningcorporatie De Woonplaats Fons Catau door hun commitment aan het algemeen welzijn 'new civic leadership', een nieuwe vorm van burgerlijk leiderschap (Hambleton, 2015: 152-156; Reussing, 2017a).

Waar in de eerste periode de radicale vernieuwers van de gemeentepolitiek hun inspiratie opdeden in het buitenland, met name in Groot-Brittannië, is er in de laatste periode ook een toenemende belangstelling in het buitenland voor het optreden van spraakmakende en grensverleggende Nederlandse bestuurders. Dat blijkt bijvoorbeeld uit het burgemeestersboek van Benjamin Barber, waarin hij een pleidooi houdt voor een wereldwijd parlement van burgemeesters. ${ }^{40}$ In Amsterdam maakte Job Cohen indruk als burgemeester (van 2001 tot 2010) toen de spanningen in 2004 escaleerden in het kielzog van de moord op de cineast Theo van Gogh. Cohen reageerde toen met een moedig beleid van toenadering en verdraagzaamheid, maar ook met een harde aanpak van de misdaad op basis van de vervolging van zogenaamde veelplegers. Met zijn aanpak, die even pragmatisch als visionair was, wist hij de rust in Amsterdam te herstellen. Eberhard van der Laan (2010 tot 2017) was net als zijn voorganger lid van de PvdA, maar hij toonde als burgemeester een grote partijpolitieke onafhankelijkheid en verwierf met die

39 In 2008 kreeg de gemeente Enschede ook internationale erkenning door het ontvangen van de eerste prijs bij de European Urban and Regional Planning Awards (EURPA) in de categorie 'Regional participation'.

40 Nummer 2015/1 van dit tijdschrift is een debatnummer over het boek van Benjamin Barber. De debatbijdragen zijn vrij toegankelijk op: https://tijdschriften.boombestuurskunde.nl/tijdschrift/ bw/2015/1. 
opstelling zowel binnen Amsterdam als over de landsgrenzen heen veel respect. Zijn grote sympathie voor de zaak van de gerechtigheid (bijvoorbeeld bij de uitvoering van het raadsbesluit over kraken) verleidde hem niet tot minachting van de markten. Hij was daarom trots op de status van Amsterdam als handels- en beurscentrum, die in niets onderdeed voor haar status als cultuurhoofdstad. In Rotterdam dankte Ahmed Aboutaleb zijn benoeming als burgemeester in 2009 evenzeer aan zijn competentie en slagvaardigheid als aan zijn multiculturele achtergrond. Hij was niet alleen de eerste moslim die burgemeester werd van een grote stad in Nederland, maar ook de eerste van allochtone komaf en met een dubbele (de Nederlandse en de Marokkaanse) nationaliteit. Alleen al zijn aanwezigheid in Rotterdam vormt in de ogen van Barber een triomf van het pragmatisme over ideologische scherpslijperij en etnische bekrompenheid (Barber, 2014: 411-416; zie ook Cohen, 2009)..$^{41}$

\section{Kenmerken van grensverleggende bestuurders}

In dit essay is intussen een groot aantal 'grensverleggers' de revue gepasseerd. Zij moesten in elke periode een antwoord geven op de vragen, problemen en uitdagingen van hun tijd. Tot de grote opgaven van deze tijd behoort het streven naar ecologische duurzaamheid (de energietransitie) en naar maatschappelijke duurzaamheid (het integratievraagstuk). Volgens René Cuperus (2018) is maatschappelijke duurzaamheid minstens zo urgent als ecologische duurzaamheid. Voor het aanpakken van deze opgaven moeten opnieuw grenzen worden verlegd. Welke eisen stelt dat aan onze bestuurders? Hoe kunnen zij succesvol opereren in onze complexe en dynamische netwerksamenleving? De huidige globale problemen waarmee ook onze gemeenten worden geconfronteerd vragen om lokale bestuurders die een goede mix bezitten van politiek leiderschap, nieuw burgerlijk leiderschap, inspirerend opdrachtgeverschap en goed rentmeesterschap. Zij moeten immers opereren op het snijvlak van politiek en samenleving en van droom en daad.

De traditionele eigenschap waarmee goede bestuurders zich onderscheiden is politiek leiderschap. Uit de studie naar bestuursstijlen van wethouders van Gerard Schouw uit 1996 is een aantal belangrijke aspecten van politiek leiderschap te destilleren. Het gaat zowel om vrouwen als mannen die zich na enige jaren bestuurservaring in de lokale politiek invloedrijk en machtig hebben weten te maken. Zij zien hun werk als iets bijzonders, als een soort roeping om dingen te veranderen, doelen te bereiken en voorstellen in gang te zetten. Ze hebben forse invloed op het beleids- en besluitvormingsproces, zowel wat betreft de inhoud van de besluiten als het verloop van dat proces. Zij geven doelbewust richting aan

41 Voor onze Vlaamse lezers vermeld ik dat Barber (2014: 412-413) ook de oud-burgemeester van Antwerpen Patrick Janssens noemt als voorbeeld van een uitstekend en spraakmakend bestuurder in de Lage Landen. Tot zijn genoegen constateert Barber dat ook diens rechtspopulistische opvolger Bart De Wever 'door het stadhuis' tot matiging en pragmatisme is genoopt, zelfs als hij daar zijn eigen ideologische piketpaaltjes probeert te plaatsen. 


\section{Figuur $7 \quad$ Grensverleggend bestuur tussen politiek en samenleving en tussen} droom en daad

\begin{tabular}{|c|c|}
\hline $\begin{array}{l}\text { Politiek leiderschap } \\
\text { ('political leadership') }\end{array}$ & $\begin{array}{r}\text { Goed rentmeesterschap } \\
\text { ('good stewardship') }\end{array}$ \\
\hline $\begin{array}{l}\text { ('inspiring commissioning') } \\
\text { Inspirerend opdrachtgeverschap }\end{array}$ & $\begin{array}{l}\text { SAMENLEVING } \\
\text { ('new civic leadership') } \\
\text { Nieuw burgerlijk leiderschap }\end{array}$ \\
\hline
\end{tabular}

het werk van anderen en geven (bedenk daarbij wel dat het bestuursstelsel in 1996 nog monistisch was) niet alleen richting aan de besluitvorming in het college van $B \& W$, maar zijn tegelijkertijd de leiders van de gemeenteraad, van hun fractie en van hun politieke partij. Politieke leiders lijken besturen mede te beschouwen als het 'spelen' van een interessant en ingewikkeld spel voor het verkrijgen van een meerderheid voor een voorstel. Politieke leiders vertrouwen sterk op zichzelf en minder op de mensen in hun omgeving. De meest karakteristieke eigenschappen van de stijl zijn een duidelijke opvatting over onderwerpen, het vasthouden aan standpunten, het gezag in politieke organen, de manier waarop andere actoren worden overtuigd en het denken en handelen vanuit strategieën (Schouw, 1996: 118). Kijken we naar ons historisch overzicht dan waren deze eigenschappen bij mannen als Treub, Wibaut, Drees, Van der Ploeg en Schaefer ruimschoots aanwezig.

Het overzicht laat ook zien dat we in onze complexe en dynamische netwerksamenleving (zie het voorbeeld van Ed Wallinga in Enschede) bestuurders nodig hebben die ook beschikken over wat Robin Hambleton nieuw burgerlijk leiderschap ('new civic leadership') heeft genoemd. De vier kernelementen van burgerlijk leiderschap (zie Hambleton, 2015: 166) zijn: (a) dat leiders nieuwe ruimtes creëren voor mensen met een verschillende achtergrond om samen te komen en van elkaar te leren, (b) dat leiders ervoor zorgen dat de juiste mensen in deze ruimtes terechtkomen, (c) dat leiders werkwijzen ontwikkelen die openheid en moedig gedrag bevorderen en die anderen helpen om van hun angst voor verandering of falen af te komen, en (d) dat leiders hun persoonlijk commitment laten zien en zich bewust zijn van de emoties bij anderen. Deze vier kernelementen van leiderschap zijn extra van belang in een turbulente beleidsomgeving waarin gemeenten en hun bestuurders te maken hebben met de gevolgen van decentralisaties, bezuinigingen en verschuivende beleidsdoelstellingen (Reussing, 2017a). Een voorbeeld is de opkomst van een aanpak die zich primair richt op het ondersteunen van burgerkracht en waarin er niet alleen wordt gewerkt aan sociaal herstel, maar ook aan activering naar werk of andere participatievormen (Oude Vrielink e.a., 2014). Nieuw burgerlijk leiderschap kan ook worden gezien als het bestuurlijke 
pendant van burgerschap onder de leden van de samenleving. In de woorden van Job Cohen (2009: 136-137) moet burgerschap geworteld raken in de stad en kan het gemeentebestuur daarbij behulpzaam zijn door burgerinitiatieven te ondersteunen en te faciliteren. Het is daarbij voor hem vanzelfsprekend dat burgerschap zich richt tot alle burgers en niet uitsluitend tot de nieuwkomers. Burgerschap kan eraan bijdragen dat burgers elkaar meer vertrouwen.

Lokale bestuurders bewegen zich niet alleen op het snijvlak van politiek en samenleving, maar ook op het snijvlak van droom en daad (zie o.a. Vulperhorst, 2014). Het werk van bestuurders heeft een idealistische en een praktische kant. Het voorbeeld van de wederopbouw van de wijk Roombeek in Enschede (onder de bestuurlijke verantwoordelijkheid van wethouder Roelof Bleker) laat zien dat aan de praktische kant van het werk van lokale bestuurders inspirerend opdrachtgeverschap geboden is. De basis van inspirerend opdrachtgeverschap is altijd goed opdrachtgeverschap. Waar een gemeente samenwerkt met andere partijen is goed opdrachtgeverschap van belang om regie op de samenwerking te kunnen voeren. Daarom moet duidelijk zijn wat de opdracht is, wat er wordt uitgesloten, waarop er gestuurd kan worden en waarover verantwoording wordt afgelegd. De VNG ${ }^{42}$ noemt als vier principes van goed opdrachtgeverschap: (a) de eigen en de gemeenschappelijke wensen en belangen van de verschillende partners in beeld brengen, (b) de taken, bevoegdheden en verantwoordelijkheden van het samenwerkingsverband bepalen, (c) de prestaties van het samenwerkingsverband nader afbakenen, en (d) de opdrachtcyclus inrichten, inclusief een tijdige en open informatievoorziening. Het extra element dat inspirerend opdrachtgeverschap aan goed opdrachtgeverschap toevoegt, is de creatieve, deskundige en bezielende wijze waarop de opdrachtgever de voorwaarden voor de uiteindelijke (in het geval van 'De Gouden Piramide' architectonische) kwaliteit van het eindresultaat optimaliseert. ${ }^{43}$ In het voorbeeld van Roombeek ging het om de manier waarop geëxperimenteerd werd met nieuwe vormen van bewonersparticipatie en met diverse vormen van particulier opdrachtgeverschap.

De idealistische kant van het werk van lokale bestuurders betreft hun visie op de ontwikkeling van de gemeente op de langere termijn, voorbij de horizon van de vierjarige raadsperiode. In de inleiding op deze paragraaf is gesproken over de noodzaak het streven naar ecologische duurzaamheid (de energietransitie) en naar maatschappelijke duurzaamheid (het integratievraagstuk) te combineren. Dat vereist een visie op het bestuur van de gemeente die uitgaat van goed rentmeesterschap. Rentmeesterschap is een term uit de klassieke oudheid en heeft daar betrekking op de functie van financieel beheerder en hoofdopzichter in een

42 De vier principes van goed opdrachtgeverschap zijn ontleend aan de website van de Vereniging van Nederlandse Gemeenten (VNG): https://vng.nl/producten-diensten/diensten/vraagstukken/ goed-opdrachtgeverschap

43 De formulering is ontleend aan de Regeling Rijksprijs voor inspirerend opdrachtgeverschap 'De Gouden Piramide'; zie de vijfde overweging in de publicatie van deze regeling in de Staatscourant op 25 februari 2003. 
bedrijf, maar ook op de functie van de wachter (in de zin van toezichthouder). ${ }^{44}$ Later kreeg het begrip een meer uitgebreide betekenis: mensen zijn verantwoordelijk voor een zorgvuldig beheer van de wereld waarin zij leven, voor de mensen met wie zij omgaan en voor de zaken die aan hun zorgen zijn toevertrouwd (zie Woldring, 1996: 38-40). Het gedrag van rentmeester is economisch in de oorspronkelijke betekenis van het Griekse woord oikonomia en staat tegenover chrematistikè als streven naar zelfverrijking (Goudzwaard, 1978: 255-257). ${ }^{45}$ Peter Block (2013) beschouwt als kern van het begrip rentmeesterschap ('stewardship') de keuze voor dienstbaarheid boven eigen belang. Vertaald naar lokaal bestuur gaat goed rentmeesterschap over een langetermijnvisie op de gemeente die zich kenmerkt door drie aspecten: (a) zorg voor de wereld om ons heen (de ecologische duurzaamheid), (b) zorg voor de mensen om ons heen (de maatschappelijke duurzaamheid), en (c) zorg voor de middelen die aan ons zijn toevertrouwd (het financieel beheer).

Met het kwartet politiek leiderschap, nieuw burgerlijk leiderschap, inspirerend opdrachtgeverschap en goed rentmeesterschap hebben we vier kenmerken besproken van grensverleggende bestuurders die van belang zijn in de huidige tijd. Ze zijn alle vier nodig voor een goede balans tussen politiek en samenleving en tussen droom en daad. Wel kan het gewicht van deze kenmerken verschillen per onderwerp en per fase in het beleidsproces. Ook zullen en hoeven de kenmerken niet gelijk over alle bestuurders zijn verdeeld. Met een variant op de indeling (politiek, juridisch, economisch, technisch- en sociaalwetenschappelijk) van de dit jaar overleden bestuurskundige Ig Snellen (1987) kunnen deze vier kenmerken worden opgevat als vier niet tot elkaar herleidbare rationaliteiten: politiek leiderschap als politieke rationaliteit, nieuw burgerlijk leiderschap als sociale rationaliteit, inspirerend opdrachtgeverschap als juridisch-technische rationaliteit en goed rentmeesterschap als economische rationaliteit (in de brede klassieke betekenis van het woord). Naar mijn mening is de wetenschappelijke rationaliteit (verschillende soorten kennis die nodig zijn) relevant voor alle vier andere rationaliteiten.

\section{Tot besluit}

Aan het eind van dit lange essay wil ik toch nog kort ingaan op de lessen uit dit historisch overzicht van smaakmakende bestuurders en grensverleggend bestuur. In de eerste periode (voor 1910) zagen we dat de 'grensverleggers' vooral uit de kringen van de progressieve liberalen (de radicalen) kwamen. In de daarop volgende perioden zien we dat in grote en middelgrote steden (al zijn er ook grote

44 In bestuurskundige literatuur (zie Schillemans, 2013) wordt de 'stewardship theory' toegepast als tegenhanger van de 'agency theory' om toezichtsrelaties te beschrijven die uitgaan van gedeelde waarden en normen.

45 De econoom Bob Goudzwaard en de filosoof Henk Woldring maakte ik mee als inspirerende docenten aan de Vrije Universiteit. Beide CDA-ideologen hebben intussen hun partij verlaten. Goudzwaard stapte in 1980 over naar de EPV uit teleurstelling over de behoudende koers van het CDA; Woldring zegde in 2010 zijn lidmaatschap op uit protest tegen de samenwerking met de PVV en noemt zich sindsdien een 'wachtende kiezer' (Van Turnhout, 2015). 
verschillen per gemeente) de sociaaldemocratie de dominante factor werd in het bepalen van de koers van de gemeentepolitiek. Veel grensverleggende gemeentebestuurders kwamen voort uit de SDAP of de PvdA. Deze dominantie is vanaf 1990 geleidelijk afgenomen en na de raadsverkiezingen van 2014 (definitief) ten einde gekomen. In deze periode deden veel nieuwe lokale partijen hun intrede in de gemeentepolitiek, vaak uit protest tegen de bouwplannen van het stadsbestuur en de als regentesk ervaren bestuursstijl. De bekendste voorbeelden van die nieuwe protestpartijen zijn Leefbaar Hilversum van Jan Nagel, dat in 1994 in één klap de grootste partij in de raad werd, en Leefbaar Utrecht van Henk Westbroek, dat in 1998 vanuit het niets negen zetels wist te behalen. Deze partijen plaveiden de weg voor Leefbaar Rotterdam dat in 2002 met Pim Fortuyn de grootste partij in de Rotterdamse gemeenteraad werd en de dominante partij in het college van B\&W. Deze partijen kunnen populistisch worden genoemd, omdat zij appelleerden aan gevoelens van onvrede en achterstelling bij de kiezer en zich afzetten tegen de lokale bestuurlijke elites (Boogers e.a., 2018: 166-167).

In de periode daarna heeft de opkomst van lokale partijen zich doorgezet (lang niet allemaal populistisch) met als voorlopig hoogtepunt de gemeenteraadsverkiezingen van 2018 waarbij deze partijen landelijk ruim 32\% van de stemmen behaalden. Ook de electorale neergang van de klassieke volkspartijen PvdA en CDA (dominant in de plattelandsgemeenten) en de toegenomen steun voor partijen als D66, GroenLinks en de SP (de VVD was wel in staat haar positie te handhaven) heeft geleid tot een toenemende versnippering van de gemeenteraden (Boogers e.a., 2018: 167-169). Deze versnippering heeft geleid tot de noodzaak coalities te vormen die bestaan uit een groot aantal partijen en nieuwe bestuurders uit die partijen te rekruteren. De samenstelling van het vorige en het huidige kabinet-Rutte laat zien dat de lokale politiek nog steeds fungeert als kraamkamer en leerschool voor de landelijke politiek (Boogers, 2010: 41-62). Diverse bewindslieden waren ervoor wethouder of burgemeester, zoals Lodewijk Asscher (PvdA) in Amsterdam, Ivo Opstelten (VVD) in Rotterdam, Eric Wiebes (VVD) in Amsterdam, Melanie Schultz van Haegen (VVD) in Leiden, Sander Dekker (VVD) in Den Haag, Henk Kamp (VVD) in Borculo, Jetta Klijnsma (PvdA) in Den Haag, Mark Harbers (VVD) in Rotterdam, Kajsa Ollongren (D66) in Amsterdam, Ingrid van Engelshoven (D66) in Den Haag, Ank Bijleveld (CDA) in Hof van Twente, Barbara Visser (VVD) in Zaanstad, Mona Keijzer (CDA) in Purmerend, Tamara van Ark (VVD) in Nieuwerkerk aan den IJssel en Zuidplas, Hugo de Jonge (CDA) in Rotterdam, Paul Blokhuis (ChristenUnie) in Apeldoorn en Bruno Bruins (VVD) in Den Haag.

Er zijn uiteraard ook goede en grensverleggende bestuurders bij andere partijen en onder hen die het (nog) niet tot bewindspersoon schopten (of in een verder verleden minister waren). Zonder anderen te kort te willen doen, volgt een (uiteraard persoonlijk gekleurd) rijtje spraakmakende bestuurders in het huidige decennium: Rob van Gijzel (PvdA, burgemeester in Eindhoven), Jozias van Aartsen (VVD, burgemeester in Den Haag), Jan van Zanen (VVD, burgemeester in Utrecht), Peter den Oudsten (PvdA, burgemeester in Enschede en Groningen), 
Henk Jan Meijer (VVD, burgemeester in Zwolle), Andries Heidema (ChristenUnie, burgemeester in Deventer), Paul Depla (PvdA, burgemeester van Heerlen en Breda), Annemarie Jorritsma (VVD, burgemeester in Almere), Ahmed Marcouch (PvdA, burgemeester in Arnhem), Ferd Crone (PvdA, burgemeester in Leeuwarden), Pauline Krikke (VVD, burgemeester in Arnhem en Den Haag), Onno van Veldhuizen (D66, burgemeester in Enschede), Marijke van Hees (PvdA, wethouder in Enschede), Lot van Hooijdonk (GroenLinks, wethouder in Utrecht), Staf Depla (PvdA, wethouder in Eindhoven), Maarten van Poelgeest (GroenLinks, wethouder in Amsterdam), Eric van der Burg (VVD, wethouder in Amsterdam), Simone Kukenheim (D66, wethouder in Amsterdam), Arjan Vliegenthart (SP, wethouder in Amsterdam), Joost Eerdmans (Leefbaar Rotterdam, wethouder in Rotterdam), Jeroen Hatenboer (VVD, wethouder in Enschede), Eelco Eerenberg (D66, wethouder in Enschede), Hans van Agteren (Burgerbelangen, wethouder in Enschede), Jurgen van Houdt (ChristenUnie, wethouder in Enschede) en Patrick Welman (CDA, wethouder in Enschede. Met Emile Roemer (tussen 2002 en 2006 wethouder in de gemeente Boxmeer) levert de SP dit jaar in Heerlen zijn eerste (waarnemend) burgemeester. Lilian Janse maakt op dit moment kans om in Vlissingen de eerste vrouwelijke wethouder voor de SGP te worden (Besselink, 2018). ${ }^{46}$

De versnippering in de gemeentepolitiek heeft ook gevolgen voor de positie van de burgemeester. Die positie heeft in de loop van de tijd flinke veranderingen ondergaan. Eerst werd hij van magistraat (vanaf 1848) tot manager en politiek ondernemer (vanaf 1931), daarna tot iemand met beperkte bevoegdheden, maar met een belangrijke coördinerende en samenbindende taak (vanaf 1970). Tegenwoordig is hij degene die door de nog steeds aanwezige autoriteit van het ambt en het toenemende belang van vraagstukken op het gebied van de openbare orde een vooraanstaande plaats in het gemeentebestuur inneemt. De gemeenteraad heeft tegenwoordig een beslissende invloed op aanstelling, herbenoeming en ontslag van de burgemeester (Cohen \& Holla, 2018: 239-240). De versnippering in de gemeentepolitiek en de opgaven waarvoor de gemeentebesturen staan, maken het des te belangrijker goed na te denken over de invulling van het ambt en de aanstellingswijze na de deconstitutionalisering van de aanstellingswijze (Karsten e.a., 2014; Van Ostaaijen e.a., 2017). Een andere ontwikkeling is de trend om te kiezen voor een partijloze burgemeester. De gastvrouw van het VNG-jaarcongres 2018, de burgemeester van Maastricht Annemarie Penn-te Strake, is ook partijloos, maar ze heeft haar roots in het zuiden. Het is daarom interessant te volgen hoe ze (als kleindochter van ondernemer Bertus te Strake en burgemeester Lambert Roefs en na een carrière bij de rechterlijke macht en het openbaar ministerie) haar rol als burgemeester invult.

De redactie van Bestuurswetenschappen mag zich met Job Cohen (PvdA, Amsterdam) niet alleen verheugen over de aanwezigheid van een gerenommeerd oud-burgemeester, maar heeft met Milo Schoenmaker (VVD, Gouda) en Laurens de Graaf (CDA, Lopik) ook twee leden die op dit moment het ambt van burgemeester uitoefenen. 


\section{Literatuur}

Agteren, P. van, R. van Middelkoop \& C. van Wijk (eds.), Jan van der Ploeg, vernieuwer in Rotterdam. Terugblik op een loopbaan, PvdA Gewest Rotterdam, Rotterdam: 1982.

Barber, B.R., Als burgemeesters zouden regeren. Haperende staten, opkomende steden, Amsterdam: 2014.

Beek, P. e.a. (eds.), 'Ik ben dus een stadsmens'. John Wevers, 20 jaar wethouder stadsontwikkeling in Maastricht, Maastricht: 1994 (het citaat in de titel is van John Wevers zelf).

Berg, J.T.J. van den \& G. Boogaard, 'De gemeenteraad in Nederland. Schets van de staatsrechtelijke en politieke geschiedenis', J.P. Vollaard, G. Boogaard, J.T.J. van den Berg \& M.J. Cohen (eds.), De gemeenteraad. Ontstaan en ontwikkeling van de lokale democratie, Amsterdam: 2018, p. 41-78.

Berg, M. van den, 'Jongens, maak het maar mooi'. Stadsontwikkelaar en ambtenaar in Amsterdam, Bussum: 2016 (met een nawoord van Zef Hemel, het citaat in de titel is van Cornelis van Eesteren).

Besselink, N., 'Lilian Janse mogelijk eerste vrouwelijke SGP-wethouder', Trouw, 23 maart 2018.

Bleich, A., Joop den Uyl 1919-1987. Dromer en doordouwer, Amsterdam: 2008.

Block, P., Stewardship. Choosing service over self-interest, San Francisco, CA: 2013 (second edition).

Boogers, M.J.G.J.A., Lokale politiek in Nederland. De logica en dynamiek van plaatselijke politiek, Den Haag: 2010 (tweede druk, eerste druk 2007).

Boogers, M.J.G.J.A., R. de Jong \& G. Voerman, 'Politieke partijen. Van zakelijk notabelenbestuur naar politieke profilering', J.P. Vollaard, G. Boogaard, J.T.J. van den Berg \& M.J. Cohen (eds.), De gemeenteraad. Ontstaan en ontwikkeling van de lokale democratie, Amsterdam: 2018, p. 151-171.

Borrie, G.W.B., Pieter Lodewijk Tak. Journalist en politicus, Assen: 1973.

Borrie, G.W.B., F.M. Wibaut. Mens en magistraat, Den Haag: 1987 (tweede druk, eerste druk 1968).

Borrie, G.W.B., 'Emanuel Boekman en de gemeentepolitiek', E. Boekman e.a., Het leven als leerschool. Portret van Emanuel Boekman 1889-1940, Amsterdam: 1989, p. 45-60.

Borrie, G.W.B., Monne de Miranda. Een biografie, Den Haag: 1993.

Borrie, G.W.B., Het leven als een te voltooien bouwwerk. Vijf portretten van vrijmetselaren, Zutphen: 2000 (een van de hoofdstukken gaat over Pieter Oud).

Borrie, G.W.B., M.A. Reinalda (1888-1965). Een geboren bestuurder, Amsterdam: 2005.

Bosmans, J., Romme. Biografie 1896-1946, Utrecht: 1991.

Braam, A. van, Een eeuw Zaandam 1870-1970. Sociaal-economische studies betreffende de historische en de vermoedelijke toekomstige ontwikkeling der gemeente Zaandam, Zaandam: 1949.

Briggs, A., Victorian cities, Londen: 1968 (eerste druk 1963).

Buursink, D., Getekend. Uit het dagboek van een wethouder in Enschede na de vuurwerkramp op zaterdag 13 mei 2000, Enschede: 2002.

Cohen, M.J., Binden, Amsterdam: 2009 (met een inleidend interview door Bas Heijne).

Cohen, M.J. \& M. Holla, 'Gemeenteraden en de burgemeester', J.P. Vollaard, G. Boogaard, J.T.J. van den Berg \& M.J. Cohen (eds.), De gemeenteraad. Ontstaan en ontwikkeling van de lokale democratie, Amsterdam: 2018, p. 225-240.

Couperus, S., De machinerie van de stad. Stadsbestuur als idee en praktijk, Nederland en Amsterdam 1900-1940, Amsterdam: 2009. 
Crawford, R., 'Glasgow's experience with municipal ownership and operation. Water, gas, electricity and street railways', The Annals of the American Academy of Political and Social Science, 1906/1, p. 1-19.

Cuperus, R., 'Ik maak me drukker om onze maatschappelijke dan om onze ecologische duurzaamheid', De Volkskrant, 4 maart 2018.

Depla, P.F.G. \& J.S. Monasch, 'Het wethouderssocialisme. De PvdA en de lokale democratie', P.W. Tops, A.F.A. Korsten \& C.A.T. Schalken (eds.), De wethouder. Positie en functioneren in een veranderend bestuur, Den Haag: 1994, p. 255-267.

Droogleever Fortuyn, P., Het organisme ener grote stad, Amsterdam: 1923.

Esveld, N.E.H. van, Treub. Over de drempel der nieuwe samenleving, Assen: 1958.

Gaemers, J., De rode wethouder. Willem Drees 1886-1988: de jaren 1886-1940, proefschrift Universiteit van Amsterdam, Amsterdam: 2006.

Gehrke, J.P., 'A radical endeavour. Joseph Chamberlain and the emergence of municipal socialism in Birmingham', American Journal of Economics and Sociology, 2016/1, p. 23-57.

Gerritsz, J. (ed.), Modern gemeentebeheer, Rotterdam: 1909.

Goudzwaard, B., Kapitalisme en vooruitgang, Assen/Amsterdam: 1978 (tweede herziene druk).

Hambleton, R., Leading the inclusive city. Place-based innovation for a bounded planet, Bristol: 2015.

Hazeu, C.A., N.G.J. Boonstra, M. Jager-Vreugdenhil \& P. Winsemius, Buurtinitiatieven en buurtbeleid in Nederland anno 2004. Analyse van een veldonderzoek van 28 casussen, WRR, Amsterdam: 2005.

Hoeks, L., 'In geouwehoer kun je niet wonen'. Het leven van Jan Schaefer, Amsterdam: 2017 (het citaat in de titel is van Jan Schaefer zelf).

Kaal, H.G.J., Het hoofd van de stad. Amsterdam en zijn burgemeester tijdens het interbellum, proefschrift Vrije Universiteit Amsterdam, Amsterdam: 2008 (over burgemeester Willem van der Vlugt).

Kalk, E., De rode geranium. Leven en werk van Eiske ten Bos-Harkema (1885-1962), de eerste vrouwelijke wethouder van de SDAP in Nederland, Amsterdam: 2005.

Karsten, N., L. Schaap \& F. Hendriks, 'Krachtig en kwetsbaar. De Nederlandse burgemeester en de staat van een hybride ambt', Bestuurswetenschappen, 2014/3, p. 48-67.

Kennedy, J.C., Nieuw Babylon in aanbouw. Nederland in de jaren zestig, Amsterdam/Meppel: 1995.

Knol, M., Waarom wethouder, Staatshuys innoverend organiseren, Zwolle: 2017.

Liagre Böhl, H. de, Amsterdam op de helling. De strijd om stadsvernieuwing, Amsterdam: 2010.

Liagre Böhl, H. de, Steden in de steigers. Stadsvernieuwing in Nederland 1970-1990, Amsterdam: 2012.

Liagre Böhl, H. de, Wibaut de Machtige. Een biografie, Amsterdam: 2013.

Liagre Böhl, H. de, 'De vier giganten van politiek leiderschap', L. Vulperhorst (ed.), Praktische dromers. Over het vak van wethouder, herziene editie, Amsterdam: 2014, p. 129-149.

Liagre Böhl, H. de, Amsterdammer in de polder. Han Lammers (1931-2000), Amsterdam: 2015 (met Maarten Ternede als co-auteur).

Maas, P.F., Sociaal-democratische gemeentepolitiek in katholiek Nijmegen 1894-1927, proefschrift Katholieke Universiteit Nijmegen, Nijmegen: 1974.

Maas, P.F., Sociaal-democratische gemeentepolitiek 1894-1929, Den Haag: 1985 (deze publicatie bevat het algemene deel van het proefschrift van Maas uit 1974).

Maver, I., Glasgow, Edinburgh: 2000 (boek in de serie Town and City Histories). 
Metz, T, 'Scheidende PvdA-wethouder over drie sterke generaties stadsbestuurders. Asselbergs en zijn herwaardering van de stad', NRC Handelsblad, 31 maart 1993.

Michels, A.M.B., 'Burgerparticipatie in het beleid, bewonersinitiatieven, en de rol van de gemeenteraad', J.P. Vollaard, G. Boogaard, J.T.J. van den Berg \& M.J. Cohen (eds.), De gemeenteraad. Ontstaan en ontwikkeling van de lokale democratie, Amsterdam: 2018, p. 191-205.

Miranda, S.R. de, Pro Domo, verklaard en toegelicht door Gilles Borrie, Frans Heddema en Geert Mak, Amsterdam/Antwerpen: 1997.

Oosten, F. van, De stad en de wethouder. Hoe Cees Waal de binnenstad van Leiden vernieuwde, Leiden: 2017.

Ostaaijen, J.J.C. van, N. Karsten \& P.W. Tops, 'De aanstellingswijze gewogen. Een overzicht van argumenten voor en tegen verschillende aanstellingswijzen van de burgemeester', Bestuurswetenschappen, 2017/4, p. 5-24.

Oude Vrielink, M.J., L. Sterrenberg \& H. Koper, 'Uitvoeringskracht in sociale wijkteams. Een beproefd concept in een nieuwe context', Bestuurswetenschappen, 2014/2, p. 32-46.

Poelje, G.A. van, Hedendaags gemeentewezen, Alphen aan den Rijn: 1963.

Reussing, G.H., 'Pionieren met wijkcoaches in Enschede. KISS kon ons nog meer vertellen', Bestuurswetenschappen, 2017a/1, p. 70-89.

Reussing, G.H., 'John Wevers. Een leven in de Maastrichtse politiek', Bestuurswetenschappen, 2017b/2, p. 60-79.

Reussing, G.H., 'De vroege geschiedenis van de (lokale) bestuurswetenschappen. Jos van der Grinten als bondgenoot van Gerrit van Poelje', Bestuurswetenschappen, 2018/1, p. 64-87.

Reussing, G.H., M.J.G.J.A. Boogers \& S.A.H. Denters, 'Gemeenteraden en regionale samenwerking', J.P. Vollaard, G. Boogaard, J.T.J. van den Berg \& M.J. Cohen (eds.), De gemeenteraad. Ontstaan en ontwikkeling van de lokale democratie, Amsterdam: 2018, p. 257-278.

Ruyter-de Zeeuw, C.A. de, De eerste rode wethouders van Rotterdam, Rotterdam: 1987.

Schillemans, T., 'Moving beyond the clash of interests. On stewardship theory and the relationships between central government departments and central agencies', Public Management Review, 2013/4, p. 541-562.

Schouw, A.G., Bestuursstijlen van wethouders. Functioneren in de praktijk, Den Haag: 1996.

Slijkerman, D., In dienst van de Kroon. Vice-presidenten van de Raad van State, Zutphen: 2001 (een van de hoofdstukken gaat over Willem van Leeuwen).

Slijkerman, D., Enfant terrible. Wim Treub (1858-1931), Amsterdam: 2016.

Snellen, I.T.M., Boeiend en geboeid. Ambivalenties en ambities in de bestuurskunde, oratie Katholieke Universiteit Brabant, Alphen aan den Rijn: 1987.

Tammes, K.C., Dwarsligger van beroep: ridder van Rappard (1906-1994). De spraakmakendste burgemeester van Nederland, Amsterdam: 2018.

Treub, M.W.F., Herinneringen en overpeinzingen, Haarlem: 1931.

Turnhout, M. van, 'Wachten tot het CDA zijn bron herontdekt', interview met Henk Woldring, Trouw, 4 maart 2015.

Veen, H.N. ter (met sociografische nota's van J. Diederich en A. Hoekstra), Problemen der samenvoeging van Zaangemeenten, Haarlem: 1941.

Veldheer, V., Kantelend bestuur. Onderzoek naar de ontwikkeling van taken van het lokaal bestuur in de periode 1851-1985, proefschrift Universiteit Leiden, Rijswijk: 1994a.

Veldheer, V., 'De wethouder. Van assessor tot politicus', P.W. Tops, A.F.A. Korsten \& C.A.T. Schalken (eds.), De wethouder. Positie en functioneren in een veranderend bestuur, Den Haag: 1994b, p. 25-35. 
Vriesema, I., 'In zo'n geval reken je op Jan Mans', NRC Handelsblad, 25 april 2013.

Vulperhorst, L. (ed.), Praktische dromers. Over het vak van wethouder, herziene editie, Amsterdam: 2014.

Wallage, J., Het land achter de heuvels. Politiek als ambacht, 1968-2018, Amsterdam: 2018.

Wevers, J.M.H.M., Eigenwijs in Maastricht. Terugblik op een leven in de Maastrichtse politiek, Maastricht: 2016.

Wibaut, F.M., Levensbouw. Memoires, Amsterdam: 1936.

Woldring, H.E.S., De christen-democratie. Een kritisch onderzoek naar haar politieke filosofie, Utrecht: 1996. 